\title{
Effects of Chlorophyll-Derived Efflux Pump Inhibitor Pheophorbide $a$ and Pyropheophorbide $a$ on Growth and Macrolide Antibiotic Resistance of Indicator and Anaerobic Swine Manure Bacteria
}

\author{
Mareike Kraatz, ${ }^{1}$ Terence R. Whitehead, ${ }^{1}$ Michael A. Cotta, ${ }^{1}$ \\ Mark A. Berhow, ${ }^{1}$ and Mark A. Rasmussen ${ }^{2}$ \\ ${ }^{1}$ National Center for Agricultural Utilization Research, ARS, USDA, 1815 N. University Street, Peoria, IL 61604, USA \\ ${ }^{2}$ Leopold Center for Sustainable Agriculture, 209 Curtiss Hall, Iowa State University, Ames, IA 50011, USA \\ Correspondence should be addressed to Terence R. Whitehead; terry.whitehead@ars.usda.gov
}

Received 21 October 2013; Revised 12 December 2013; Accepted 19 December 2013; Published 11 February 2014

Academic Editor: Federico Pea

Copyright (C) 2014 Mareike Kraatz et al. This is an open access article distributed under the Creative Commons Attribution License, which permits unrestricted use, distribution, and reproduction in any medium, provided the original work is properly cited.

\begin{abstract}
Natural plant compounds, such as the chlorophyll a catabolites pheophorbide a (php) and pyropheophorbide a (pyp), are potentially active in the gastrointestinal tracts and manure of livestock as antimicrobial resistance-modifying agents through inhibition of bacterial efflux pumps. To investigate whether php, a known efflux pump inhibitor, and pyp influence bacterial resistance, we determined their long-term effects on the MICs of erythromycin for reference strains of clinically relevant indicator bacteria with macrolide or multidrug resistance efflux pumps. Pyp reduced the final MIC endpoint for Staphylococcus (S.) aureus and Escherichia (E.) coli by up to 1536 and $1024 \mu \mathrm{g}$ erythromycin $\mathrm{mL}^{-1}$ or 1.4 - and 1.2 -fold, respectively. Estimation of growth parameters of $S$. aureus revealed that pyp exerted an intrinsic inhibitory effect under anaerobic conditions and was synergistically active, thereby potentiating the effect of erythromycin and partially reversing high-level erythromycin resistance. Anaerobe colony counts of total and erythromycin-resistant bacteria from stored swine manure samples tended to be lower in the presence of pyp. Tylosin, php, and pyp were not detectable by HPLC in the manure or medium. This is the first study showing that pyp affects growth and the level of sensitivity to erythromycin of S. aureus, E. coli, and anaerobic manure bacteria.
\end{abstract}

\section{Introduction}

Agricultural antimicrobial drug use is regarded a major driver of one of today's foremost global public health challenges: more frequent clinical antimicrobial treatment failures due to resistant microorganisms [1-4]. In the U.S. swine and other livestock production, much of the use of antimicrobials is nontherapeutic and/or occurs in the form of free-choice medicated feeds and water $[1,2,5]$. This results in exposures of the animals' gastrointestinal tract and waste microbiota to inconsistent, often sublethal or subinhibitory concentrations $[1,6]$. As even ultralow ( $\ll$ MIC) antimicrobial concentrations can confer a selective pressure towards the persistence of resistance in microbial communities [7-12], induction of gut and waste microbial resistance is an inevitable collateral effect of oral antimicrobials in animal agriculture [13-16].
More than 335 million tons (dry weight) of manure, a valuable fertilizer, are produced by U.S. agriculture per year [17]. Soil amendment with manure presents a significant route of transmission of antimicrobial resistance from livestock bacteria to human clinical pathogens $[4,18-$ 24]. Of greatest concern in this context is the increasing prevalence of multidrug resistance (MDR), especially in Gram-positive pathogens, such as Staphylococcus (S.) aureus, Streptococcus pneumonia, and enterococci $[25,26]$. MDR is frequently caused by bacterial efflux pumps that primarily confer broader, compound nonspecific functions unrelated to antimicrobials and are ubiquitous among bacteria $[22,25$, 27-29]. MDR is a baseline resistance for the emergence of further resistance mechanisms, and, due to its physiological determination, it naturally persists [29-32]. 
Plants have recently been recognized as an important source for the discovery and development of compounds with efflux pump inhibitor (EPI) activity $[26,33]$. The pharmacological inhibition of active efflux by adjuvant application of phytogenic EPIs presents a promising strategy for the mitigation of bacterial MDR [29, 31-34]; however, due to intrinsic toxicity among other factors, so far no EPI/antimicrobial drug combination is used clinically $[29,35]$. In this study, we aimed at investigating whether pheophorbide $a$ (php) and pyropheophorbide $a$ (pyp), catabolites of the major green plant pigment chlorophyll $a$ [36], would influence resistance of clinically relevant indicator bacteria and anaerobic bacteria from stored swine manure to the macrolide antibiotics erythromycin and tylosin.

Php and pyp can be ingested preformed in various green foods and feedstuffs [37-41], or in humans swine and other nonruminant livestock species can be produced from chlorophyll $a$ or chlorophyllide $a$ by acidity in the stomach (php) and microbial enzymes in the large intestine (php; pyp) (Figure 1) [36, 42-44]. Prior research further indicates that despite apparently undergoing an enterohepatic circulation [45-48], php and pyp are mostly excreted with no change and hence appear in a dietary concentration-dependent manner as the predominant chlorophyll catabolites in feces [43, 49, 50]. The EPI activity of php was first deduced from its berberine- and norfloxacin-potentiating, antimicrobial effect against S. aureus bearing the NorA MDR pump [51]. Later on, this effect was extended to ciprofloxacin and other strains of $S$. aureus, S. epidermidis, Escherichia (E.) coli, and Pseudomonas aeruginosa [52]. An EPI activity of pyp has not been reported at the time of writing.

Discovered in 1952 as the first macrolide antibiotic, erythromycin is now the representative of its class. Although its application in human medicine has diminished over time due to increased bacterial resistance [53], it is still an important alternative against human respiratory and food-borne infections [31, 54-56]. In U.S. agriculture, erythromycin is approved for in-feed application for swine, cattle, and poultry. It is also routinely used in the corn ethanol industry, entailing the risk of inadvertent exposure of livestock to residues in distillers' by-products, such as dried distillers' grains with solubles (DDGS) [57-59]. Erythromycin is a 14-membered ring macrolide and a narrow-spectrum antibiotic, as it is effectively extruded by MDR efflux pumps in many Gramnegative bacteria [60]. In Gram-positive bacteria, efflux is the main mechanism of erythromycin resistance besides rRNA target modification [61]. The related veterinary 16-membered ring macrolide tylosin can spur bacterial resistance to erythromycin [62-64]. It is estimated to be quantitatively the second most common in-feed antimicrobial in the U.S. swine production [5] and is also approved for cattle and poultry [59].

\section{Materials and Methods}

2.1. Bacterial Reference Strains. S. aureus ATCC 29213, Enterococcus (Ent.) faecalis ATCC 29212, Salmonella (Sal.) enterica serovar Typhimurium ATCC 14028, and porcine E. coli strains P286.10.99.C3 and P475.10.99.C3 were used for the determination of the effects of php and pyp on the MIC of erythromycin. The previously reported MIC of erythromycin ( $\mu \mathrm{g} \mathrm{mL}^{-1}$ ) was $0.25-0.5$ (S. aureus), 2-256 (Ent. faecalis), 128->256 (Sal. Typhimurium), and >256 (E. coli) [65-67]. The strains are best characterized as possessing the following MDR and macrolide efflux pumps: NorA (S. aureus), EmeA (Ent. faecalis), AcrAB-TolC (S. Typhimurium), and Mef(B) (E. coli) $[27,67]$.

\subsection{Serial Passage Selection for Induced Erythromycin Resis-} tance. Cultures with induced resistance to erythromycin were generated by serial passage of the parental (naïve) reference strains through progressively escalating doses of erythromycin. Starting at half the lower reported MIC, the strains were repeatedly subcultured depending on growth in $10 \mathrm{~mL}$ volumes of Iso-Sensitest broth (ISB, Oxoid, Ontario, Canada) with erythromycin (E6376, Sigma-Aldrich, St. Louis, MO, USA) for two (Ent. faecalis) to eight (Sal. Typhimurium) weeks under static aerobic conditions at $37^{\circ} \mathrm{C}$. Next, the strains were subcultured aerobically as well as anaerobically in an anaerobic chamber (Coy Laboratories, Ann Arbor, MI, USA) in a $96 \%$ carbon dioxide, $4 \%$ hydrogen atmosphere for another two (Ent. faecalis) to four (Sal. Typhimurium) weeks-until no further increase of the tolerated erythromycin concentration was obtained by repeated attempts.

2.3. MICs of Erythromycin over Time. The MICs of erythromycin were determined for the naive and induced reference strains under aerobic and anaerobic conditions by using the Clinical and Laboratory Standards Instituterecommended broth macrodilution method [65]. The antibiotic range of the duplicate assays routinely comprised four and maximally ten concentrations of erythromycin in ISB in doubling $\left(0.125-1024 \mu \mathrm{g} \mathrm{mL}^{-1}\right)$ or incremental (by $\left.512 \mu \mathrm{g} \mathrm{mL}^{-1} ; 1024-5632 \mu \mathrm{g} \mathrm{mL}^{-1}\right)$ steps. Assays were supplemented with either 0 (ethanol control), 0.5 , or $50 \mu \mathrm{g}$ php or pyp (both from Frontier Scientific, Logan, UT, USA) $\mathrm{mL}^{-1}$. $1: 100$ dilutions in ISB of $0.5 \mathrm{McF}$ arland-equivalent aqueous suspensions of cells grown overnight on antibiotic-free agar medium (ISB + $8 \mathrm{~g}$ antibiotic-free agar-agar (Merck, Darmstadt, Germany) $\mathrm{L}^{-1}$ ) were used as inocula. Incubation was performed for seven or 14 (induced S. aureus under anaerobic conditions) days protected from light and as described above. The MIC range defined as between the maximum tolerated concentration (MTC, highest concentration of erythromycin with visible growth in both duplicate assays) and the MIC endpoint (lowest concentration of erythromycin with no visible growth in both duplicate assays) was recorded at $20 \mathrm{~h}$, and then every $24 \mathrm{~h}$. Experiments were repeated twice.

2.4. Growth of S. aureus. The effect of pyp on the growth kinetics of naïve and erythromycin-induced cultures of $S$. aureus was analyzed using a spectrophotometric method. Aliquots of overnight cultures in antibiotic-free ISB diluted to approximately $10^{7} \mathrm{CFU} \mathrm{mL}^{-1}$ [68] were inoculated into five volumes of prewarmed ISB with $0,0.0625$ (naïve) or 


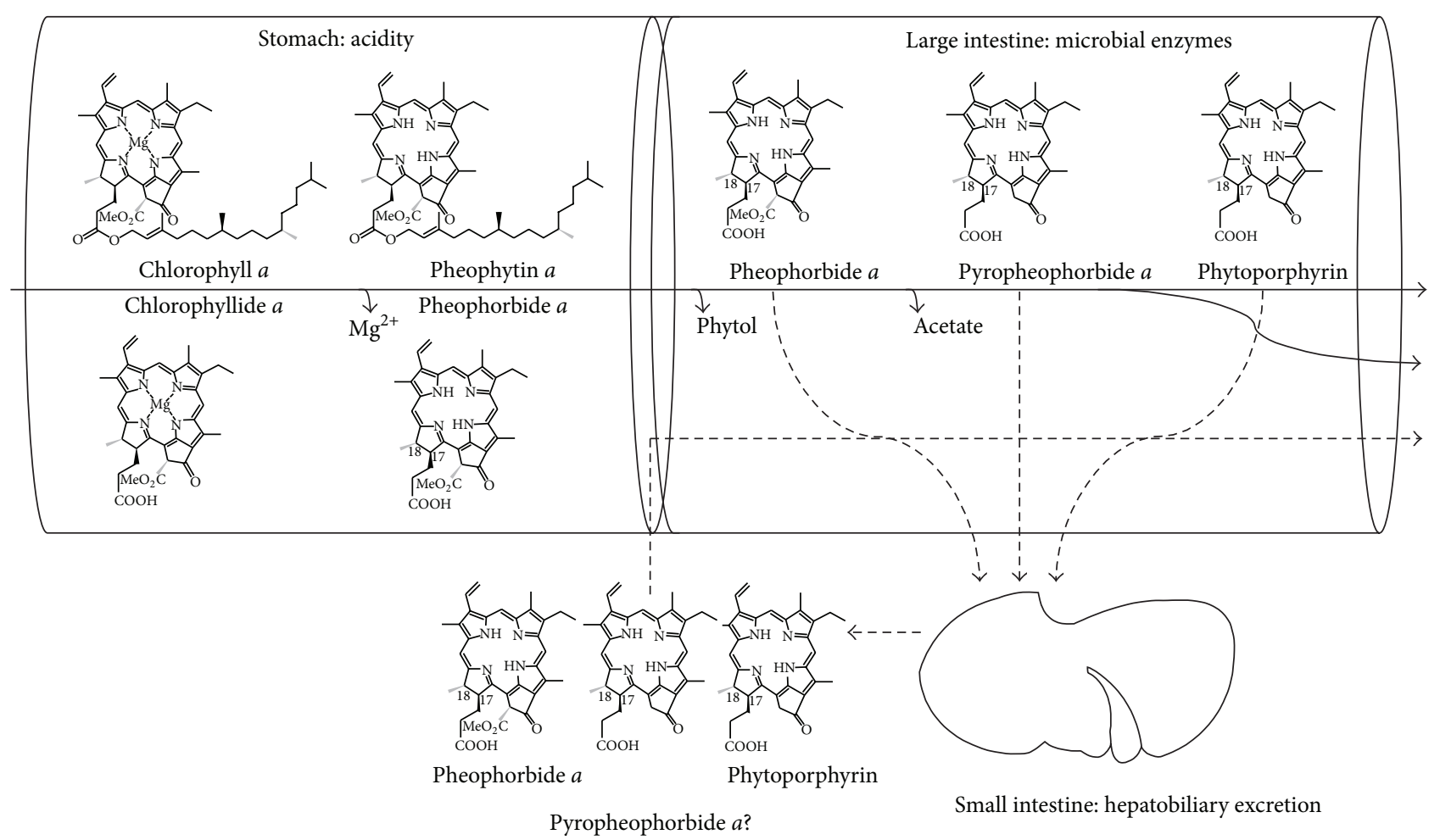

FIGURE 1: Enterohepatic metabolism of dietary chlorophyll $a$ and its catabolic derivatives in humans and nonruminant livestock.

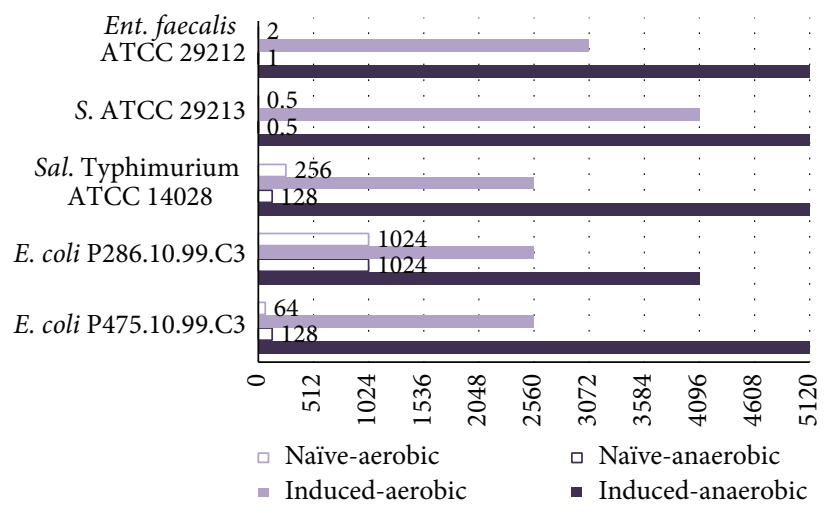

FIGURE 2: Overall maximum tolerated concentration of erythromycin $\left(\mu \mathrm{g} \mathrm{mL}^{-1}\right)$ and induction factor for reference strains of indicator bacteria.

2048 (induced) $\mu \mathrm{g}$ erythromycin $\mathrm{mL}^{-1}$ and supplemented with 0 (ethanol control), 0.5 or $50 \mu \mathrm{g}$ pyp $\mathrm{mL}^{-1}$. The assays were incubated as described above, and the culture OD was initially measured at $660 \mathrm{~nm}$ with a Beckman DU-600 spectrophotometer (Beckman Coulter, Fullerton, CA, USA) and then measured every $60 \mathrm{~min}$ over the entire incubation period $(6.5 \mathrm{~h}$ and $9.5 \mathrm{~h}$ for naïve cultures under aerobic and anaerobic conditions, resp.) or every $120 \mathrm{~min}$ between 24.5 and $36.5 \mathrm{~h}$ of incubation (induced cultures under anaerobic conditions). The total yield (maximum OD-initial OD) was calculated, as well as the average and maximum/minimum generation time, specific growth rate, and division rate [69].
All experiments were performed in duplicate and repeated three times. Results displayed in Figures 3, 4, and 5 are means plus or minus standard deviations to show the variability and reproducibility of the data.

2.5. Collection and Preparation of Swine Manure Samples. A swine farm near Peoria, IL, was used as the source of manure pit (slurry) samples. Samples from a concrete underfloor manure storage pit were collected at up to 2.4 meters (bottom of the pit) depth using sterile screw-capped $50 \mathrm{~mL}$ plastic tubes attached to a Tank Sampler (NASCO, Fort Atkinson, WI, USA). During the two-week sampling period, 875-668 finisher pigs of 21-23 weeks of age that were fed a cornsoybean-DDGS-based diet were kept in two barns above the manure pit. The pit, with a full capacity volume of approx. $1.8 \times 10^{6} \mathrm{~L}$, had been emptied on day 31 of an "all out phase" of the farm's all in-all out by building production system. This 31st day was two days before the new pigs were introduced and 94, 101, and 108 days prior to the three days of sampling. Samples were protected from light while returning to the laboratory (approx. $30 \mathrm{~min}$ ) and there immediately taken into a Coy anaerobic chamber. Approximately $25 \mathrm{~mL}$ manure was added to $2.5 \mathrm{~g}$ sterilized glass beads (Novagen ColiRollers Plating Beads, Merck) in a sterile $50 \mathrm{~mL}$ tube, vortexed gently for 10-20 s, and allowed to stand for $15 \mathrm{~min}$. Sample collection, preparation, and subsequent analytical steps were repeated twice.

2.6. Data on Zootechnical Additives and Application of Antimicrobials. Data concerning the use of feed additive premixes, 


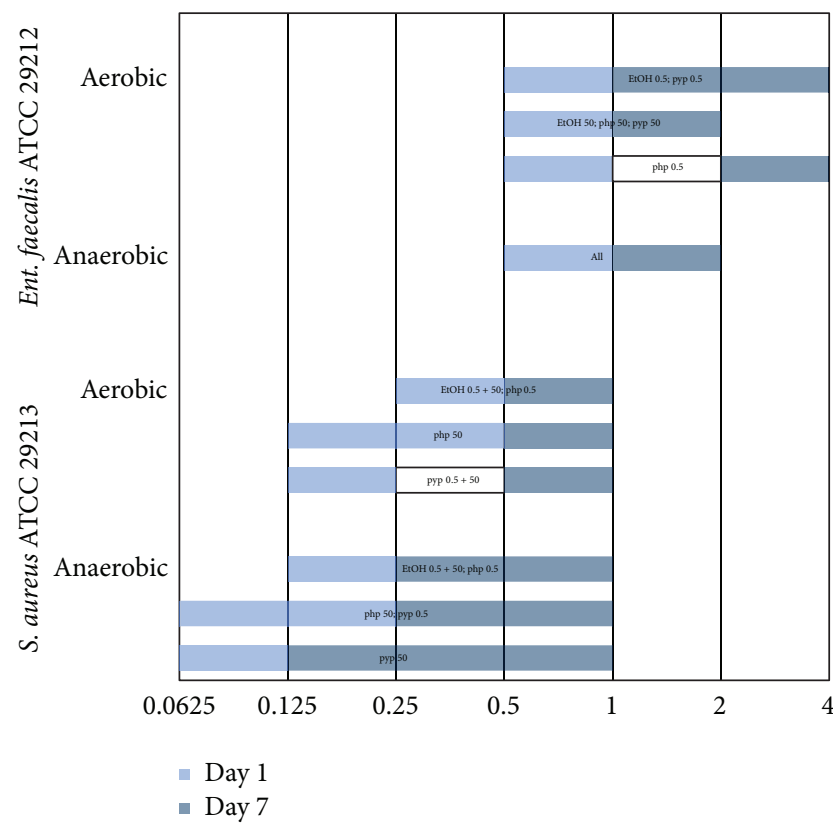

(a)

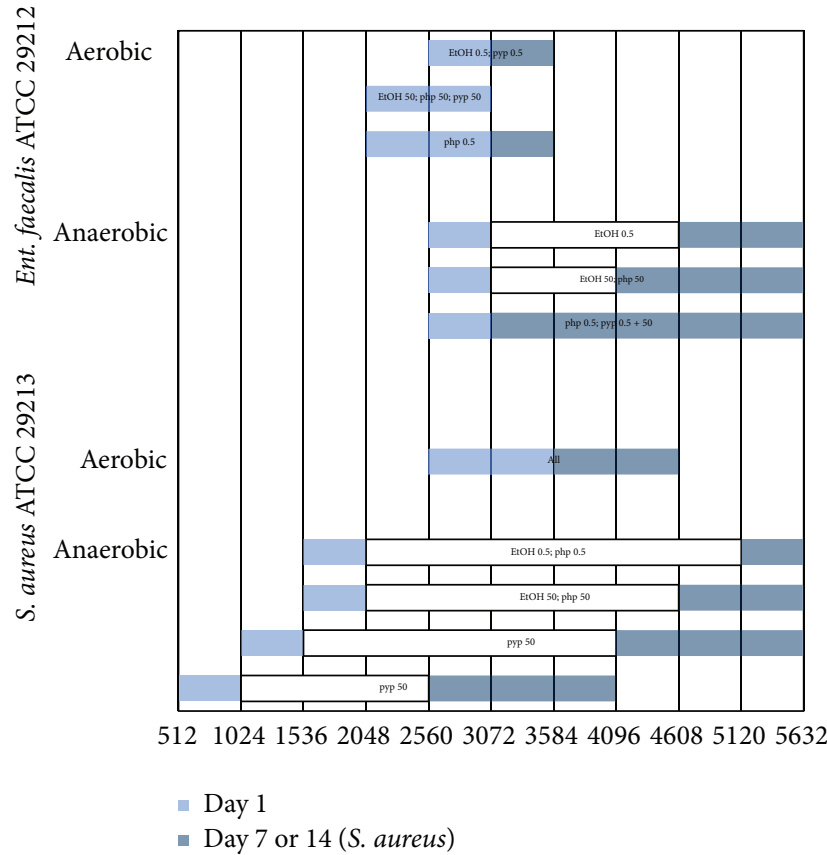

(c)

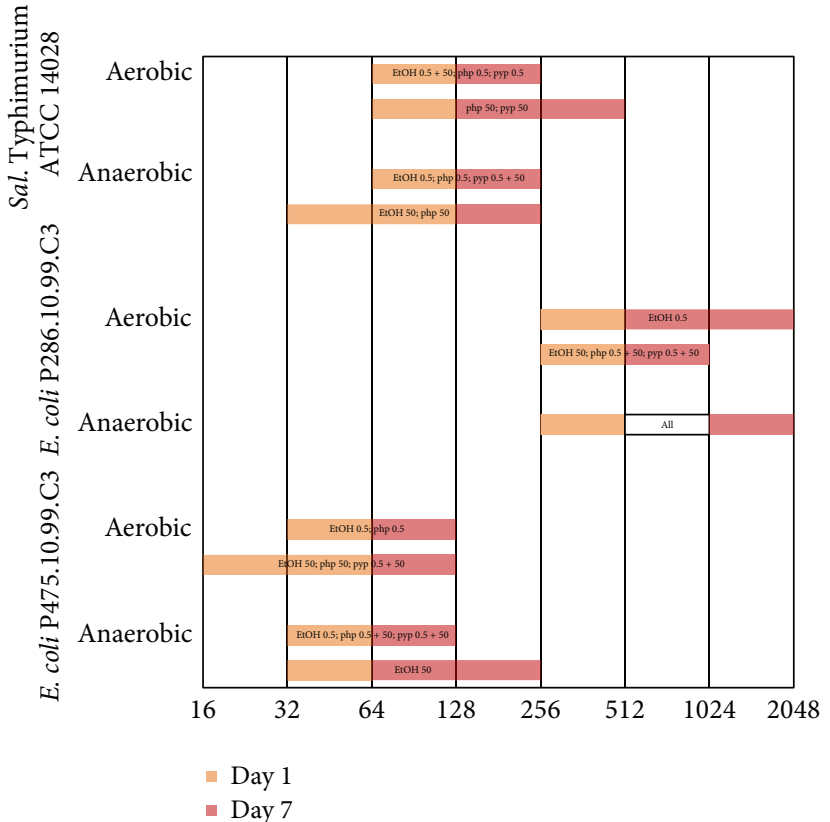

(b)

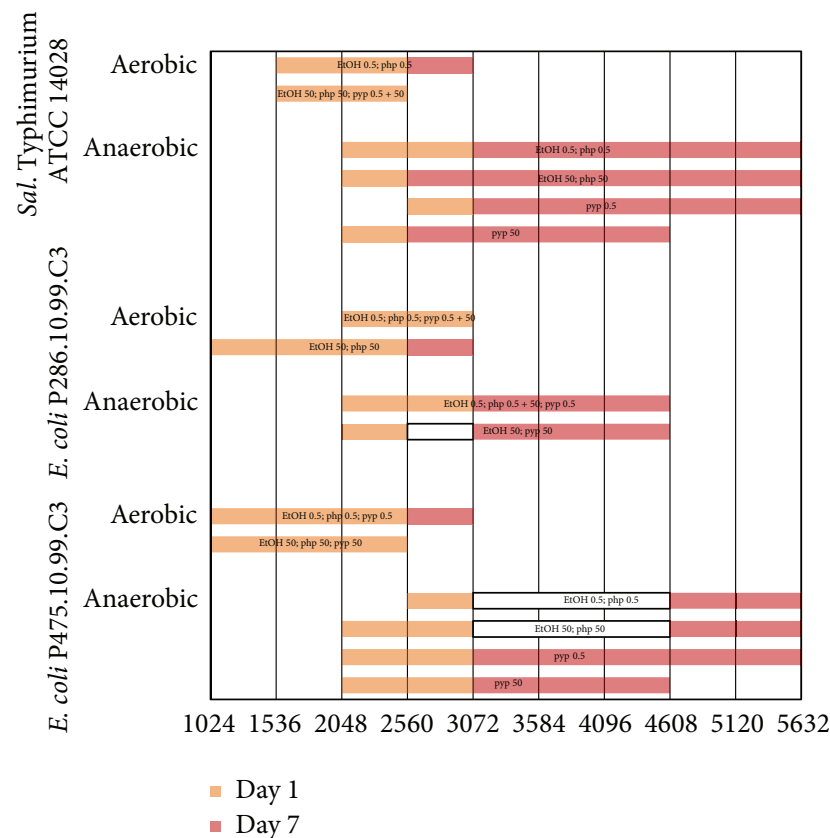

(d)

FIGURE 3: Initial (day 1) and final (day 7 or 14) MIC ranges of erythromycin ( $\mu \mathrm{g} \mathrm{mL} \mathrm{L}^{-1}$ ) for naïve (a), (b) and induced (c), (d) Gram-positive and -negative bacterial reference strains. Assays were supplemented with either 0 (EtOH 0.5, EtOH 50), 0.5, or $50 \mu \mathrm{g}$ pheophorbide $a$ (php 0.5 , php 50) or pyropheophorbide $a($ pyp 0.5 , pyp 50$) \mathrm{mL}^{-1}$.

including those with antimicrobials, and of antimicrobials by other routes of administration (in water, by injection) were obtained by request from the farm staff. The total amounts of administered antimicrobial compounds were quantified between the day of pit emptying (day 0 ) and the last day of sampling (day 108).
2.7. Total Cell Counts of Microorganisms from Stored Swine Manure. Microorganisms present in the manure samples were enumerated by direct microscopic examination using a Petroff-Hausser counting chamber (Hausser Scientific, Horsham, PA, USA). A $10 \mathrm{~mL}$-volume of a 1:10 dilution of the prepared manure supernatant in a detergent saline solution 
(9 g sodium chloride $(\mathrm{NaCl}) \mathrm{L}^{-1}$, SDS and dibasic potassium phosphate until foaming and $\mathrm{pH} 7.2-7.4$, resp.) $[70,71]$ was added to $1 \mathrm{~g}$ of glass beads, suspended by gentle vortexing for 10-20 s, and allowed to stand for $15 \mathrm{~min}$. Aliquots of the supernatant were mixed 1:1 with $0.1 \mathrm{M}$ hydrogen chloride $(\mathrm{HCl})$, and $2 \mu \mathrm{L}$ of the resulting mixture was used to fill the counting chamber. At least 400 cells counted under an Olympus BX51 phase-contrast microscope (Olympus, Center Valley, PA, USA) at $\times 2000$ magnification with oil immersion were taken into account for the calculation of the number of cells per $\mathrm{mL}$ of original sample [70].

\subsection{Viable Cell Counts of Anaerobic Bacteria from Stored} Swine Manure. To determine the numbers of anaerobic bacteria by viable plate counts, a $40 \mathrm{~mL}$ volume of a 1:100 dilution of the prepared manure supernatant in a sterile, anaerobic phosphate-buffered saline solution (PBS, $0.15 \mathrm{M}$ $\mathrm{NaCl}, 0.07 \mathrm{M}$ sodium phosphate, $\mathrm{pH} 7.0$ ) was added to $2.5 \mathrm{~g}$ of sterilized glass beads in a sterile $50 \mathrm{~mL}$ tube and vortexed gently for 10-20s. Further serial dilutions in PBS were performed on this suspension, and aliquots were plated onto anaerobically prepared [72] modified swine manure slurry medium (Slurry medium [73] containing 50\% (v/v) clarified swine manure slurry and supplemented with $1 \mathrm{~g}$ of porcine gastric mucin (M2378, Sigma-Aldrich) and $50 \mathrm{~mL}$ swine feed hydrolysate (from approx. 1g swine feed, prepared as described below) $\mathrm{L}^{-1}$ ). The nonselective, habitat-simulating slurry medium has been proven to yield the highest viable counts of anaerobic swine manure storage organisms, predominantly Firmicutes bacteria [73]. Pyp $\left(10 \mu \mathrm{g} \mathrm{m}^{-1}\right)$ was included individually and in combination with erythromycin $\left(10 \mu \mathrm{g} \mathrm{mL}^{-1}\right)$ or tylosin $\left(10 \mu \mathrm{gL}^{-1}\right.$, T-6134, Sigma-Aldrich) in some of the media. Plates were incubated anaerobically in a Coy anaerobic chamber at $37^{\circ} \mathrm{C}$, and growth on plates was examined regularly for 4 weeks and numbers of colonies enumerated.

2.9. Preparation of Hydrolyzed Swine Feed for Swine Manure Slurry Medium. A pepsin-pancreatin enzymatic hydrolysis was performed on a sample of nonmedicated swine feed obtained from the swine farm used for manure sampling following a previously described protocol $[74,75]$. This pepsinpancreatin enzymatic hydrolysis mimics the endogenous (host-derived) digestion in the porcine upper gastrointestinal tract. $1 \mathrm{~g}$, aliquots of the fine grained feed were mixed with $25 \mathrm{~mL}$ of phosphate buffer solution (0.1 M, pH 6.0) and $10 \mathrm{~mL} 0.2 \mathrm{M} \mathrm{HCl}$. The $\mathrm{pH}$ was adjusted to 2.0 with $1 \mathrm{M}$ $\mathrm{HCl}$ and $1 \mathrm{M}$ sodium hydroxide $(\mathrm{NaOH})$, and $1 \mathrm{~mL}$ of a freshly prepared porcine pepsin solution containing $25 \mathrm{mg}$ pepsin (516360, Calbiochem, San Diego, CA, USA) $\mathrm{mL}^{-1}$ was added. The mixtures were transferred into $50 \mathrm{~mL}$ glass serum bottles with rubber stoppers, and the crimp-sealed bottles were placed for $2 \mathrm{~h}$ in a gently rotating stainless steel beaker reactor system equipped with infrared heating (Labomat BFA-12 v200, Werner Mathis, Concord, NC, USA) set to $39^{\circ} \mathrm{C}$. After the pepsin hydrolysis, $10 \mathrm{~mL}$ of phosphate buffer solution $(0.2 \mathrm{M}, \mathrm{pH} 6.8)$ and $5 \mathrm{~mL} 0.6 \mathrm{M} \mathrm{NaOH}$ were added to the hydrolysis mixtures. The $\mathrm{pH}$ was adjusted to 6.8 , and $1 \mathrm{~mL}$ of a freshly prepared porcine pancreatin solution containing $100 \mathrm{mg}$ pancreatin (P-1750, Sigma) $\mathrm{mL}^{-1}$ was added. The hydrolysis step using the Labomat reactor system was repeated at $39^{\circ} \mathrm{C}$ for $4 \mathrm{~h}$. Finally, the hydrolysates were filtered through three layers of cheesecloth, and the filtrate was stored at $-18^{\circ} \mathrm{C}$ for later use.

\subsection{Concentrations of Php, Pyp, and Tylosin in Stored} Swine Manure, Hydrolyzed Feed, and Agar Medium. Php, pyp, and tylosin concentrations in the stored swine manure, hydrolyzed swine feed, and unsupplemented agar medium were determined on a wet weight basis using HPLC analysis of methanol extracts from dried samples. The concentrations of erythromycin were not analyzed, as there had been no history of erythromycin application on the farm used for manure sampling. To obtain dry materials and wet weight/dry weight ratios, the remaining manure sample and unautoclaved feed hydrolysate were spread out evenly in a plastic tray, weighed, and put in a convection oven (Blue M Electric Company, Blue Island, IL, USA) until they dry (approx. $48 \mathrm{~h}$ ) at 40 and $60^{\circ} \mathrm{C}$, respectively. 2 agar plates of the unsupplemented medium were weighed and then freeze-dried in $50 \mathrm{~mL}$ tubes with perforated lids using a Labconco Bulk Tray Dryer (Labconco, Kansas City, MO, USA) for approximately $48 \mathrm{~h}$. After reweighing, the dried samples were ground with mortar and pestle, and $3 \times 0.3 \pm$ $0.01 \mathrm{~g}$ aliquots of the resulting powders were mixed with $2 \mathrm{~mL}$ HPLC grade methanol in $20 \mathrm{~mL}$ disposable scintillation vials. The vials were capped, wrapped with sealing tape, sonicated for $30 \mathrm{~min}$ in a Branson 2510 ultrasonic cleaner (Branson Ultrasonics, Danbury, CT, USA), and allowed to stand overnight at room temperature and to be protected from light. Aliquots of the extraction supernatants were passed through a $0.45 \mu \mathrm{m}$ nylon chromatography syringe filter (Fisher Thermo Scientific, Pittsburgh, PA, USA) into $1.5 \mathrm{~mL}$ screw-thread vials (SUN-Sri, Rockwood, TN, USA) for HPLC analysis for both pheophorbides, php and pyp, and tylosin.

HPLC analysis was conducted on a Shimadzu LC-20 HPLC system (LC-20AT quaternary pump, DGU-20A5 degasser, SIL-20A HT autosampler, and a SPD M20A photodiode array detector, running under Shimadzu LCSolutions version 1.22 chromatography software, Shimadzu, Columbia, MD, USA). The column used was an Inertsil ODS-3 reverse phase C-18 column $(5 \mu \mathrm{M}, 250 \times 4.6 \mathrm{~mm}$, Varian Lake Forrest, CA, USA). For php and pyp analysis, the initial conditions were from $50 \%$ acetonitrile and $50 \%$ water with $0.025 \%$ trifluoroacetic acid (TFA) at a flow rate of $1 \mathrm{~mL}$ per minute. The effluent was monitored at $410 \mathrm{~nm}$ on the photodiode array (PDA) detector. After injection (typically $25 \mu \mathrm{L}$ ), the column was developed to $100 \%$ acetonitrile and $0.025 \%$ TFA in a linear gradient over 30 minutes. Standard curves based on micrograms injected were prepared from a preparatory standard of php from chlorophyll $a$ (C5753, Sigma-Aldrich) [76] and pure standard of pyp purchased commercially from Frontier Scientific. For tylosin analysis, the initial conditions were $10 \%$ acetonitrile, $90 \%$ water, with $0.025 \%$ TFA at a flow rate of $1 \mathrm{~mL}$ per minute. The effluent was monitored at 285 
and $210 \mathrm{~nm}$ on the PDA detector. After injection (typically $25 \mu \mathrm{L}$ ), the column was held at the initial conditions for 5 minutes and then developed to $100 \%$ acetonitrile and $0.025 \%$ TFA in a linear gradient over 30 additional minutes. Standard curves based on $\mu \mathrm{g}$ tylosin injected were prepared from commercially obtained standard (Sigma-Aldrich).

\section{Results}

3.1. Serial Passage Selection for Induced Erythromycin Resistance. Figure 2 shows the MTCs of erythromycin for the naïve strains and after serial passage selection in progressively increasing erythromycin concentrations for 4 (Ent. faecalis) to 12 weeks (Sal. Typhimurium). The level of parental but not of induced resistance was higher in the Gram-negative strains (parental: 64-1024, induced: 2560-5120 $\mu \mathrm{g}$ erythromycin $\mathrm{mL}^{-1}$ ) than in the Gram-positives (parental: 0.5-2, induced: $3072-5120 \mu \mathrm{g} \mathrm{mL}^{-1}$ ). For all strains, induction was higher under anaerobic than under aerobic conditions, with the maximum factor being 10240 (S. aureus).

3.2. MICs of Erythromycin over Time. The most notable effects on the MICs of erythromycin were observed in pypsupplemented assays of $S$. aureus. The initial MIC range of naïve cultures of $S$. aureus was 2 -fold lower both under aerobic ( $0.25-0.5$ in controls versus $0.125-0.25$ in assays with pyp at 0.5 and $\left.50 \mu \mathrm{g} \mathrm{mL}^{-1}\right)$ and anaerobic (0.125-0.25 in control versus $0.0625-0.125$ in assays with pyp at $50 \mu \mathrm{g} \mathrm{mL}^{-1}$ ) conditions (Figure 3(a)). For induced cells under anaerobic conditions, the initial MIC range was reduced by $512 \mu \mathrm{g}$ erythromycin $\mathrm{mL}^{-1}$ or $1.3-1.5$-fold (pyp at $0.5 \mu \mathrm{g} \mathrm{mL}^{-1}$ ) to $1024 \mu \mathrm{g}$ erythromycin $\mathrm{mL}^{-1}$ or 2 -3-fold (pyp at $50 \mu \mathrm{g} \mathrm{mL}^{-1}$ ) (Figure 3(c)). Using the higher concentration of pyp, this initial effect was stable over time (up to 14 days) with a reduction of the final MIC end point by $1536 \mu$ g erythromycin $\mathrm{mL}^{-1}$ or 1.4-fold (Figure 3(c)). Pyp was more effective against $S$. aureus under anaerobic conditions, and insofar as, in naïve cultures, the increase of MIC endpoints to the final value of 1 occurred later (day 7) than under aerobic conditions (days 3-4) (Figure 3(a), details not depicted), and insofar as no differences occurred on aerobically grown-induced cultures (Figure 3(c)). The effect of pyp (at $50 \mu \mathrm{g} \mathrm{mL}^{-1}$ ) was less on E. coli P475.10.99.C3 (reduction of the final MIC endpoint of induced cultures by $1024 \mu \mathrm{g}$ erythromycin $\mathrm{mL}^{-1}$ or 1.2 -fold under anaerobic conditions, Figure $3(\mathrm{~d})$ ) and not significant on the other strains. MICs in php-supplemented assays were unaffected or insignificantly different (Figures 3(a)-3(d)).

3.3. Growth of $S$. aureus. In general, results from the spectrophotometric analysis of the growth kinetics of $S$. aureus confirmed a concentration-dependent inhibitory effect of pyp. In naïve cultures under aerobic conditions, the growthretarding effect of $0.0625 \mu \mathrm{g}$ erythromycin $\mathrm{mL}^{-1}$ was synergistically potentiated by $50 \mu \mathrm{g}$ pyp $\mathrm{mL}^{-1}$, resulting in a significantly longer generation time $g$ (minimum $g\left(g_{\min }\right)=$ $54.6 \pm 3.7 \mathrm{~min}$, average $\left.g\left(g_{\text {ave }}\right)=71.1 \pm 2.0 \mathrm{~min}\right)$ and reduced growth rate $k\left(\operatorname{maximum} k\left(k_{\max }\right)=0.33 \pm 0.02 \mathrm{~h}^{-1}\right.$, average $\left.k\left(k_{\text {ave }}\right)=0.25 \pm 0.01 \mathrm{~h}^{-1}\right)$ compared with cultures that contained only erythromycin $\left(g_{\min }, g_{\text {ave }}, k_{\max }\right.$ and $k_{\text {ave }}=49.3 \pm 0.9 \mathrm{~min}, 61.9 \pm 1.6 \mathrm{~min}, 0.37 \pm 0.01 \mathrm{~h}^{-1}$ and $0.29 \pm 0.01 \mathrm{~h}^{-1}$, resp.) (Figures 4(a), 4(b), and 5(a)). Under anaerobic conditions, 0.5 and $50 \mu \mathrm{g}$ pyp $\mathrm{mL}^{-1}$ exerted an additive to synergistic effect in combination with $0.0625 \mu \mathrm{g}$ erythromycin $\mathrm{mL}^{-1}$. Using the higher pyp concentration significantly increased $g_{\text {min }}$ and $g_{\text {ave }}$ (from $63.7 \pm 5.0$ to $73.1 \pm 3.5 \mathrm{~min}$ and $79.7 \pm 2.1$ to $85.9 \pm 1.5 \mathrm{~min}$, respectively, Figure $4(\mathrm{a})$ ) and reduced $k_{\max }$ and $k_{\text {ave }}$ (from $0.29 \pm 0.02$ to $0.25 \pm 0.01 \mathrm{~h}^{-1}$ and $0.23 \pm 0.01$ to $0.21 \pm 0.00 \mathrm{~h}^{-1}$, resp., Figure $4(\mathrm{~b}))$, as reflected by a lower total yield $(0.84 \pm 0.03$ versus $0.68 \pm 0.08$, Figures $4(\mathrm{c})$ and $5(\mathrm{~b}))$. Furthermore, pyp at $50 \mu \mathrm{g} \mathrm{mL}^{-1}$ exhibited an intrinsic growth-inhibitory effect, thereby leading to an increased $g_{\text {ave }}$ (from $74.1 \pm$ 1.3 to $79.4 \pm 1.9 \mathrm{~min}$, Figure $4(\mathrm{a})$ ) and reduced $k_{\text {ave }}$ (from $0.24 \pm 0.00$ to $0.23 \pm 0.01 \mathrm{~h}^{-1}$, Figure $\left.4(\mathrm{~b})\right)$ and total yield (from $1.07 \pm 0.02$ to $0.85 \pm 0.02$, Figures $4(\mathrm{c})$ and $5(\mathrm{~b})$ ). In erythromycin-induced cultures, the combinatory effect of 0.5 and $50 \mu \mathrm{g}$ pyp $\mathrm{mL}^{-1}$ was consistently synergistic and thus partially reversed high-level erythromycin resistance (Figure 5(c)). $g_{\min }(319.8 \pm 12.3 \mathrm{~min})$ and $g_{\text {ave }}(342.3 \pm$ $14.2 \mathrm{~min})$ were significantly longer and $k_{\max }\left(0.06 \pm 0.00 \mathrm{~h}^{-1}\right)$, $k_{\text {ave }}\left(0.05 \pm 0.00 \mathrm{~h}^{-1}\right)$, and the total yield $(0.40 \pm 0.06)$ significantly reduced in the presence of both $50 \mu \mathrm{g}$ pyp $\mathrm{mL}^{-1}$ and $2048 \mu \mathrm{g}$ erythromycin $\mathrm{mL}^{-1}$ relative to cultures exposed to only erythromycin $\left(g_{\min }, g_{\text {ave }}, k_{\max }, k_{\text {ave }}\right.$, and total yield $=$ $273.7 \pm 6.0 \mathrm{~min}, 299.0 \pm 6.0 \mathrm{~min}, 0.07 \pm 0.00 \mathrm{~h}^{-1}, 0.06 \pm 0.00 \mathrm{~h}^{-1}$ and $0.59 \pm 0.03$, resp.) (Figures $4(\mathrm{a})-4(\mathrm{c})$, and $5(\mathrm{c})$ ).

3.4. Data on Zootechnical Additives and Application of Antimicrobials. The antimicrobial compounds applied between the day when the manure storage pit was emptied and the last day of the sampling period were oxytetracycline hydrochloride, lincomycin hydrochloride, tiamulin hydrogen fumarate, and penicillin $\mathrm{G}$ (benzylpenicillin) procaine in the following decreasing quantities: $6.90 \mathrm{~kg}$ oxytetracycline hydrochloride by feed, water, and injection, $5.82 \mathrm{~kg}$ lincomycin hydrochloride by feed and injection, $0.31 \mathrm{~kg}$ tiamulin hydrogen fumarate by feed and $0.15 \mathrm{~kg}$ penicillin $\mathrm{G}$ procaine by injection. There was no history of the use of erythromycin on the farm, and the last contamination of the manure pit with tylosin occurred 31 days before the pit emptying. Other applied zootechnical feed additives with antimicrobial activity were copper sulfate $(4.93 \mathrm{~kg})$ and zinc oxide $(67.77 \mathrm{~kg})$. Besides antimicrobials, $78.47 \mathrm{~kg}$ of an algaecontaining prebiotic feed additive (Intivate, Alltech, Ames, IA, USA) as well as $90.04 \mathrm{~kg}$ of MicroSource S, a direct-fed microbial feed supplement containing $1.47 \times 10^{8}$ spores of Bacillus (B.) subtilis and B. licheniformis $\mathrm{g}^{-1}$ (DSM, Parsippany, NJ, USA) [77] were applied. Intivate had first been introduced 9 months and 10 days before the pit emptying, and the amount used during this time was $53.07 \mathrm{~kg}$. Only lincomycin hydrochloride (approx. $0.12 \mathrm{~kg}$ by injection) and MicroSource S $(17.24 \mathrm{~kg})$ were administered during the twoweek sampling period. 


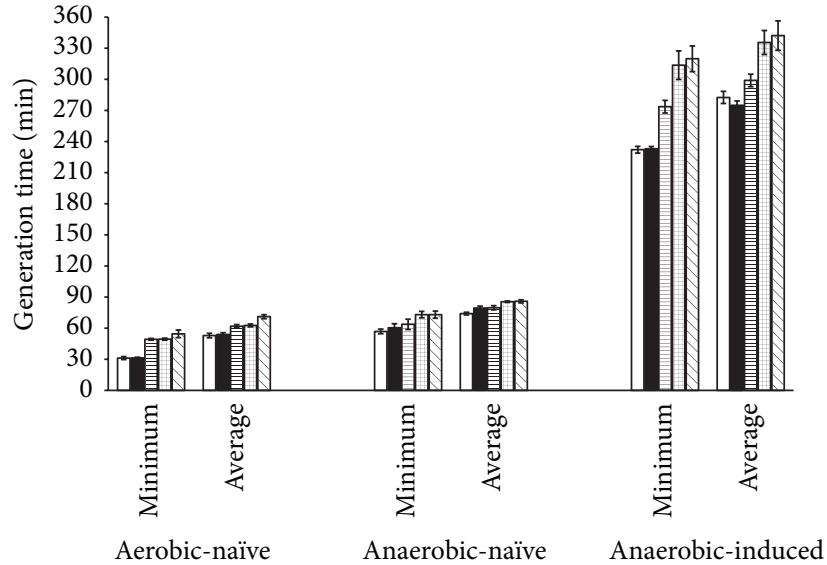

$\square \mathrm{EtOH} 5 \mu \mathrm{L} / \mathrm{mL}$ (naïve) or $45 \mu \mathrm{L} / \mathrm{mL}$ (induced)

口 pyp $50 \mu \mathrm{g} / \mathrm{mL}+\mathrm{EtOH} 5 \mu \mathrm{L} / \mathrm{mL}$ (naïve) or $45 \mu \mathrm{L} / \mathrm{mL}$ (induced)

ery $0.0625 \mu \mathrm{g} / \mathrm{mL}$ (naïve) or $2048 \mu \mathrm{g} / \mathrm{mL}$ (induced) $+\mathrm{EtOH} 5 \mu \mathrm{L} / \mathrm{mL}$

(naïve) or $45 \mu \mathrm{L} / \mathrm{mL}$ (induced)

pyp $0.5 \mu \mathrm{g} / \mathrm{mL}+$ ery $0.0625 \mu \mathrm{g} / \mathrm{mL}$ (naïve) or $2048 \mu \mathrm{g} / \mathrm{mL}$

$\square$ (induced) $+\mathrm{EtOH} 5 \mu \mathrm{L} / \mathrm{mL}$ (naïve) or $45 \mu \mathrm{L} / \mathrm{mL}$ (induced)

pyp $50 \mu \mathrm{g} / \mathrm{mL}+$ ery $0.0625 \mu \mathrm{g} / \mathrm{mL}$ (naïve) or $2048 \mu \mathrm{g} / \mathrm{mL}$

$\checkmark$ (induced) $+\mathrm{EtOH} 5 \mu \mathrm{L} / \mathrm{mL}$ (naïve) or $45 \mu \mathrm{L} / \mathrm{mL}$ (induced)

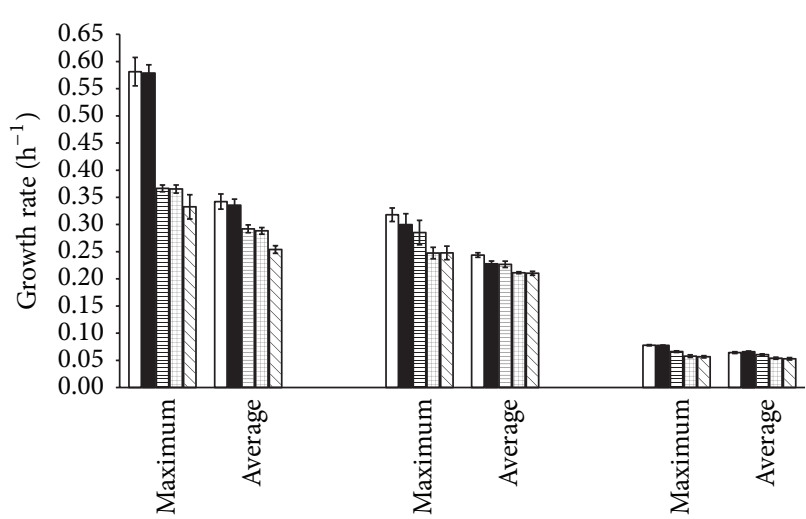

Aerobic-naïve Anaerobic-naïve Anaerobic-induced $\square \mathrm{EtOH} 5 \mu \mathrm{L} / \mathrm{mL}$ (naïve) or $45 \mu \mathrm{L} / \mathrm{mL}$ (induced)

- pyp $50 \mu \mathrm{g} / \mathrm{mL}+\mathrm{EtOH} 5 \mu \mathrm{L} / \mathrm{mL}$ (naïve) or $45 \mu \mathrm{L} / \mathrm{mL}$ (induced)

ery $0.0625 \mu \mathrm{g} / \mathrm{mL}$ (naïve) or $2048 \mu \mathrm{g} / \mathrm{mL}$ (induced) $+\mathrm{EtOH} 5 \mu \mathrm{L} / \mathrm{mL}$

(naïve) or $45 \mu \mathrm{L} / \mathrm{mL}$ (induced)

pyp $0.5 \mu \mathrm{g} / \mathrm{mL}+$ ery $0.0625 \mu \mathrm{g} / \mathrm{mL}$ (naïve) or $2048 \mu \mathrm{g} / \mathrm{mL}$

(induced) $+\mathrm{EtOH} 5 \mu \mathrm{L} / \mathrm{mL}$ (naïve) or $45 \mu \mathrm{L} / \mathrm{mL}$ (induced)

pyp $50 \mu \mathrm{g} / \mathrm{mL}+$ ery $0.0625 \mu \mathrm{g} / \mathrm{mL}$ (naïve) or $2048 \mu \mathrm{g} / \mathrm{mL}$

$\checkmark$ (induced) $+\mathrm{EtOH} 5 \mu \mathrm{L} / \mathrm{mL}$ (naïve) or $45 \mu \mathrm{L} / \mathrm{mL}$ (induced)

(a)

(b)

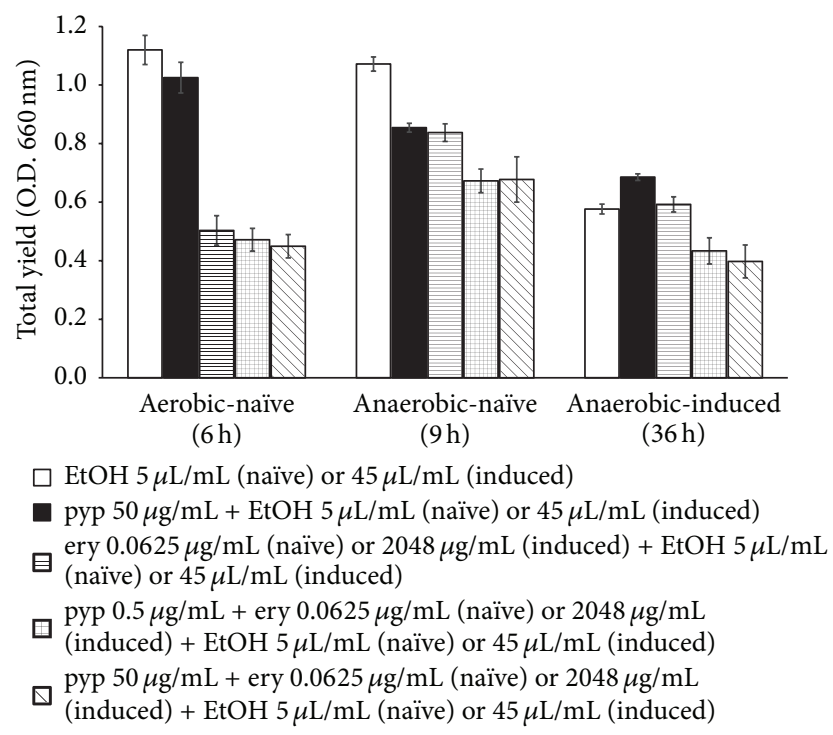

(c)

FIGURE 4: Effects of pyropheophorbide $a$ (pyp, 0.5 and $50 \mu \mathrm{g} \mathrm{mL}^{-1}$ ) alone and in combination with erythromycin (ery, 0.0625 and $2048 \mu \mathrm{g} \mathrm{mL}^{-1}$ ) on growth parameters ((a) generation time; (b) growth rate; (c) total yield) of naïve and erythromycin-induced S. aureus ATCC 29213 under aerobic and anaerobic conditions. Values are averages and standard deviations from three repeated experiments.

TABLE 1: Culture counts of anaerobic bacteria from stored swine manure.

\begin{tabular}{|c|c|c|c|c|c|c|}
\hline \multicolumn{7}{|c|}{ Viable counts: swine slurry medium* } \\
\hline & \multicolumn{2}{|c|}{$+\mathrm{H}_{2} \mathrm{O} / \mathrm{EtOH}$} & \multicolumn{2}{|c|}{ +erythromycin } & \multicolumn{2}{|c|}{+ tylosin } \\
\hline -pyp & $1.26 \times 10^{9}$ & $\left( \pm 0.13 \times 10^{9}\right)$ & $1.01 \times 10^{9}$ & $\left( \pm 0.30 \times 10^{9}\right)$ & $1.07 \times 10^{9}$ & $\left( \pm 0.15 \times 10^{9}\right)$ \\
\hline+ pyp & $8.99 \times 10^{8}$ & $\left( \pm 1.69 \times 10^{8}\right)$ & $8.90 \times 10^{8}$ & $\left( \pm 2.66 \times 10^{8}\right)$ & $1.09 \times 10^{9}$ & $\left( \pm 0.22 \times 10^{9}\right)$ \\
\hline
\end{tabular}

${ }^{*}\left(\mathrm{CFU} \mathrm{mL} \mathrm{L}^{-1}\right)$ on swine slurry medium supplemented with pyropheophorbide a (pyp, $10 \mu \mathrm{g} \mathrm{mL}{ }^{-1}$ ) alone and in combination with erythromycin, tylosin $\left(10 \mu \mathrm{g} \mathrm{mL}^{-1}\right.$, individually) or water and ethanol $\left(\mathrm{H}_{2} \mathrm{O} / \mathrm{EtOH}\right.$, control). Values are averages and standard deviations from three repeated experiments with duplicates. 


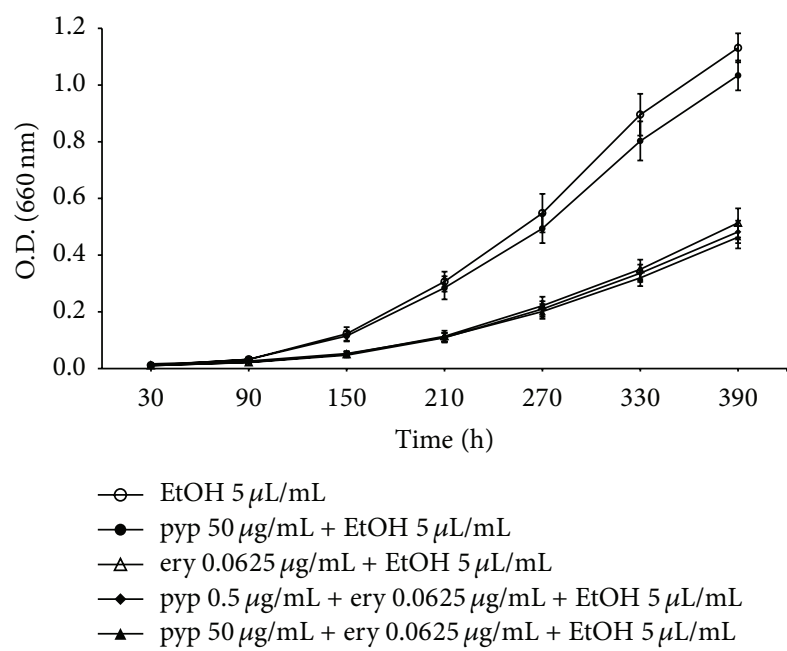

(a)

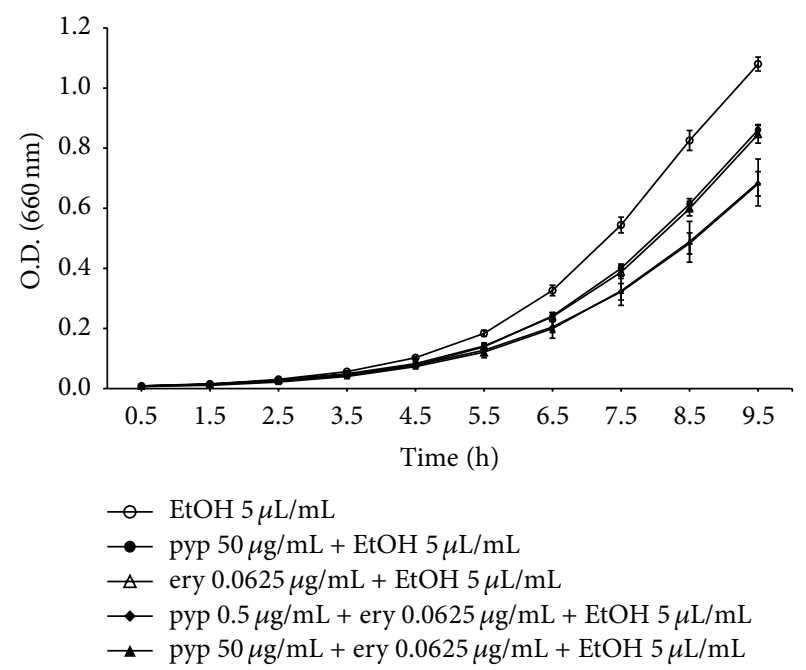

(b)

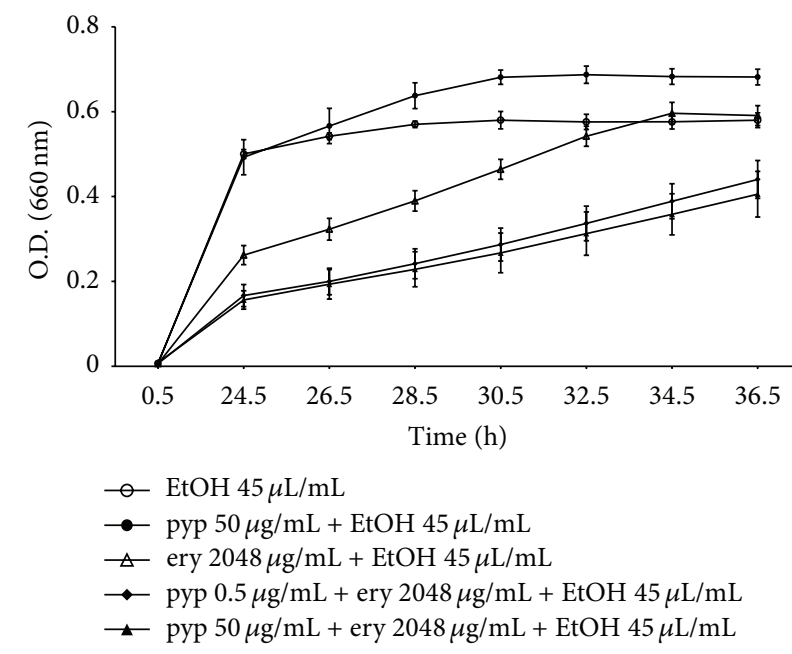

(c)

FIGURE 5: Effects of pyropheophorbide $a$ (pyp, 0.5 and $50 \mu \mathrm{g} \mathrm{mL}^{-1}$ ) alone and in combination with erythromycin (ery, 0.0625 and $2048 \mu \mathrm{g} \mathrm{mL}^{-1}$ ) on growth curves of naïve (a), (b), and erythromycin-induced (c) S. aureus ATCC 29213 under aerobic (a) and anaerobic (b), (c) conditions. Values are averages and standard deviations from three repeated experiments.

3.5. Total Cell Counts of Microorganisms and Viable Cell Counts of Anaerobic Bacteria from Stored Swine Manure. Direct microscopic counts of microorganisms in stored swine manure were $5.49 \pm 0.41 \times 10^{9} \mathrm{~mL}^{-1}$, and the recovery rate on anaerobic swine slurry medium was about $23 \%(1.26 \pm 0.13 \times$ $10^{9} \mathrm{CFU}$, Table 1). About $80 \%\left(1.01 \pm 0.30 \times 10^{9} \mathrm{CFU}\right)$ and $85 \%\left(1.07 \pm 0.15 \times 10^{9} \mathrm{CFU}\right)$ of the organisms were capable of growing in erythromycin and tylosin containing media, respectively. Pyp exerted a significant intrinsic inhibitory effect which was greater $\left(8.99 \pm 1.69 \times 10^{8} \mathrm{CFU}\right)$ than the antibiotic effect of erythromycin or tylosin. CFU on media supplemented with both pyp and erythromycin tended to be lower $\left(8.90 \pm 2.66 \times 10^{8}\right)$ than on those containing only erythromycin. This combinatorial effect was indifferent, that is, equal to the effect of pyp alone. Pyp in combination with tylosin produced an antagonistic effect, resulting in increased and equivalent counts $\left(1.09 \pm 0.22 \times 10^{9} \mathrm{CFU}\right)$ relative to the number of CFU on media containing only pyp and tylosin, respectively.

3.6. Concentrations of Php, Pyp, and Tylosin in Stored Swine Manure, Hydrolyzed Feed, and Agar Medium. Php and pyp concentrations in stored swine manure samples and unsupplemented swine slurry agar media were consistently below the general detection limit of $5 \mu \mathrm{g}$ injected or $\leq 10 \mu \mathrm{gg}^{-1}$ sample (wet weight). The concentration of tylosin or a compound with the same retention time in the unsupplemented agar media was $56.3 \pm 2.2 \mu \mathrm{g} \mathrm{g}^{-1}$ wet weight, whereas tylosin was not detected in the manure samples. Subsequent HPLC analysis of the hydrolyzed swine feed used for media preparation did not detect php, pyp, or tylosin and hence 
ruled out that the feed accounted for the possible background concentration of tylosin in the media.

\section{Discussion}

In the course of the serial passage experiments, the overall MTCs of erythromycin for naïve cultures of S. aureus and Ent. faecalis were below the European Committee on Antimicrobial Susceptibility Testing (EUCAST) epidemiological cutoff values of $\leq 1$ and $4 \mu \mathrm{g} \mathrm{mL}^{-1}$, respectively (Figure 2 and EUCAST $[78,79])$. This was presumably due to the absence of intrinsic resistance mechanisms and, because of their broad substrate specificities [80], downregulated basal expression levels of existing MDR efflux pumps, such as NorA in $S$. aureus and EmeA in E. faecalis. NorA and EmeA are homologous to each other [27, 81]; however, while EmeA is known to contribute to erythromycin resistance $[61,81]$, such a function has merely been indicated for NorA $[60,82,83]$. As with other macrolides, erythromycin is classically considered as bacteriostatic, but it has shown bactericidal activity against $S$. aureus at higher drug/cell ratios [84-86]. Bactericidal antimicrobials at sublethal concentrations induce mutational rather than adaptive resistance [10]. It is likely that the serial exposure of $S$. aureus to increasing concentrations of erythromycin ultimately resulted in the selection of cells bearing additive, high-level resistance-conferring mutations from naturally occurring subpopulations with, due to overexpression of the regular cellular machinery, low-level phenotypic adaptive resistance $[10,29,87,88]$. High-level resistance to erythromycin can be predominant among $S$. aureus strains in individual studies (approx. 60\% of strains with MIC > $1024 \mu \mathrm{g} \mathrm{mL}^{-1}$ [89]), but, generally it is rare (approx. 3\% of strains with MICs $\geq 512 \mu \mathrm{g} \mathrm{mL}^{-1}$ according to EUCAST [78]).

For all facultatively anaerobic bacterial reference strains examined, the serial passage experiments led to higher MTCs under anaerobic (96\% carbon dioxide, 4\% hydrogen atmosphere) than under aerobic conditions (Figure 2). Susceptibility testing of macrolides in the presence of carbon dioxide can result in elevated resistance, because the carbon dioxide decreases the $\mathrm{pH}$ of the medium and consequently erythromycin activity $[90,91]$. However, in our experiments, the $\mathrm{pH}$ was controlled by sodium carbonate in the media $\left(4 \mathrm{~g} \mathrm{~L}^{-1}\right)$, and therefore the " $\mathrm{pH}$ effect" of incubation in carbon dioxide can be ruled out. Instead, reactive oxygen species (ROS) generated by aeration might account for the observed differences between aerobic and anaerobic MTCs. ROS have antimicrobial activity and contribute to dysregulation primarily of MDR efflux pump expression by oxidative inactivation of global regulator proteins $[29,32]$. For example, in $S$. aureus, reduced aeration causes an increase of nor $B$ expression and hence increased resistance to antimicrobial NorB substrates via an effect on MgrA, an oxidative stresssensitive global regulator of 350 genes including nor $A$ and norB [92-94]. Thirdly, efflux-mediated antimicrobial resistance is controlled by the metabolic condition of bacteria and can be altered by a switch from an aerobic to an anaerobic metabolism through the influence of metabolically integrated global regulators, different endogenous cellular metabolites, such as ROS from aerobic respiration or anaerobic fermentation end products which often times are the natural pump substrates, and an altered transmembrane electrochemical proton gradient as energy source for secondary active transporters $[27,28,32,80]$. Hence, it can be presumed that the higher level of induced resistance in $S$. aureus under anaerobic conditions was contingent on a switch from glycolysis, the pentose phosphate pathway and ROS generating tricarboxylic acid cycle under aerobiosis to anaerobic glucose fermentation and ATPase-mediated proton efflux, generating a greater motive force for erythromycin-proton antiporters $[28,80,94]$, such as $\mathrm{LmrS}, \operatorname{MdeA}, \operatorname{Mef}(\mathrm{A})$, and conceivably NorA [27, 32, 95-97].

In the broth macrodilution assays, pyp exerted significant effects on the MICs of erythromycin for E. coli P475.10.99.C3 and especially S. aureus (Figure 3). Subsequent spectrophotometric determination of growth parameters of $S$. aureus confirmed that pyp in combination with erythromycin was most effective, that is, synergistic already at the lower concentration of $0.5 \mu \mathrm{g} \mathrm{mL}^{-1}$, in highly resistant cultures under anaerobic conditions (Figures 4 and 5(c)) and revealed that pyp was intrinsically inhibitory to anaerobic, naïve cultures (Figures 4 and 5(b)). As could be expected [8, 94], the growth rate in the absence and at a low concentration of erythromycin $\left(0.0625 \mu \mathrm{g} \mathrm{mL}^{-1}\right)$ (Figure $\left.4(\mathrm{~b})\right)$ was greatest in the aerobic, naïve cultures and lowest for the highly resistant strain-the latter effect being due to a "fitness cost" as entailed by most antimicrobial resistance mechanisms [88]. The intrinsic growth inhibition of anaerobic, naïve cultures of $S$. aureus indicates that pyp, provided it equals php in its function as an EPI [51, 52], acts against a metabolically regulated MDR pump with broader, compound nonspecific functions unrelated to antimicrobials. It can be concluded that this hypothetical MDR efflux pump is one other than NorA, as there is no strong indication of erythromycin being a NorA substrate $[29,60,82,83]$ and as we observed no significant effect of pyp against Ent. faecalis bearing the NorA homologue EmeA (Figures 3(a) and 3(c)). The S. aureus genome comprises at least 30 genes for putative drug transporters, and approximately 17 of these encode MDR efflux pumps, most of which are still unknown $[98,99]$ and two of which, LmrS and MdeA, contribute to erythromycin resistance $[27,32,97,100]$ and are therefore possible candidates for inhibition by pyp. Pyp in combination with erythromycin only partially reversed high-level resistance of $S$. aureus and did not completely inhibit its growth (Figures 3(a), 3(c), and 5(c)). This indicates that the high-level resistance is depended on the combined effects of more than one efflux pump and/or other resistance mechanisms [80]. There are at least 17 genes encoding for protein efflux systems for macrolides, lincosamides, and streptogramins [20]. $\operatorname{Msr}(\mathrm{A})$ and $\operatorname{Mef}(\mathrm{A})$ are well known to confer erythromycin resistance in strains of $S$. aureus $[27,95,96,101,102]$. The plasmidborne $\operatorname{Msr}(\mathrm{A})$ transporter, even though mainly responsible for erythromycin efflux in S. aureus [103], is not present in the strain used in our study, S. aureus ATCC 29213 [104]. Mef(A) is closely related to $\operatorname{Mef}(\mathrm{B})$, the erythromycin efflux pump in E. coli P475.10.99.C3 [67], and as pyp decreased the final 
MIC endpoint for induced cultures of this strain (Figures 3(b) and $3(\mathrm{~d}))$, it can be concluded that $\operatorname{Mef}(\mathrm{A})$ is an additional candidate for inhibition by pyp in $S$. aureus.

The basal levels of resistance to erythromycin (approx. $80 \%$ ) and tylosin (approx. 85\%) of anaerobic bacteria from stored swine manure samples (Table 1) were considerably higher than those found earlier in manure samples from the same farm (max. 21\% and 32\%) [73]. However, according to other previous studies $[105,106]$, background levels of erythromycin and macrolide resistance in nonmedicated swine fecal and manure bacterial communities can already be as high as approximately $40 \%$ and are enhanced further by the administration of compounds with antimicrobial activities [62-64]. In our study, tylosin had last been used 31 days and 4-4.5 months prior to the last pit emptying and days of sampling, respectively, and consequently was not detected by HPLC in the manure. Also, it can be concluded that instead of tylosin a different compound with the same retention time was detected in the unsupplemented agar media, as both the manure and hydrolyzed swine feed could be ruled out as a source of contamination and as any tylosin present in the media would, due to its heat lability [107], probably have been destroyed by autoclaving $\left(121^{\circ} \mathrm{C}, 20 \mathrm{~min}\right)$. There had been no history of the use of erythromycin on the farm, but a low concentration in the manure due to erythromycincontaminated DDGS in the swine feed is possible and might have contributed to the observed high basal resistance level. More likely, however, the high levels of erythromycin and tylosin resistance were partly the outcome of the recent administration of oxytetracycline, lincomycin, and the heavy metals copper and zinc, these compounds can indirectly enhance antimicrobial incl. macrolide resistance through coselection [105, 108-113].

Pyp in combination with erythromycin $\left(10 \mu \mathrm{g} \mathrm{mL}^{-1}\right.$, individually) tended to reduce the number of erythromycin resistant bacteria cultured from stored swine manure (Table 1); however, this effect was indifferent and less significant than the synergistic effects observed on S. aureus (Figures 4 and 5). The level of tylosin resistance remained unchanged when pyp and tylosin were combined (Table 1). Experiments with $S$. aureus had shown that pyp acts in a concentrationdependent manner between 0.5 and $50 \mu \mathrm{g} \mathrm{mL}^{-1}$ (Figures 35), and therefore it can be presumed that more significant effects on macrolide resistance of manure bacteria can be achieved with higher concentrations of pyp. Alternatively, the lower effectiveness might be due to cross- or coresistance between pyp and the macrolide antibiotics. The development of bacterial resistance to EPIs themselves is a recognized concern [29]. As in the experiments with S. aureus (Figures 4 and 5(b)), pyp was intrinsically inhibitory to the growth of anaerobic manure bacteria (Table 1). It is not an uncommon feature for an EPI from natural sources to possess a direct antibacterial effect $[26,35]$. For example, the aerobic MIC of php was found to vary between $4 \mu \mathrm{g} \mathrm{mL}^{-1}$ (S. epidermidis) and $500 \mu \mathrm{g} \mathrm{mL}^{-1}$ (S. aureus ATCC 29213) [52], and in another study the death percentage of $S$. aureus ATCC 26923 in $20 \mu \mathrm{g}$ php $\mathrm{mL}^{-1}$ was $32 \%$ [114]. It is conceivable that, as discussed above for $S$. aureus, pyp exerted its intrinsic effect on the manure microbiota through inhibition of a MDR efflux pump, such as LmrS, MdeA, and possibly NorA, as these and their homologues occur in B. subtilis, a major component of MicroSource $S$, and are widespread among other low mol percentage guanine-cytosine Gram-positive (phylum Firmicutes) bacteria [27, 81, 97, 100, 115-117], the predominant culturable anaerobic microorganisms from swine manure $[73,118,119]$.

Neither php nor pyp was detectable by HPLC in the swine manure or corn-soybean-DDGS-based feed (without Intivate). These results confirm previous findings that the fecal concentrations of php and pyp are diet-dependent and range between $<1$ and $180 \mu \mathrm{gg}^{-1}$ in feces (dry matter) from swine and herbivore livestock with a low and high intake of chlorophyll $a$, respectively [50]. Consequently, in order to achieve the effects indicated by our results (bacterial growth inhibition, potentiation of antimicrobials, and partial reversal of bacterial antimicrobial resistance) inside the gastrointestinal tracts of swine and/or in manure storage pits, both "hotspot habitats" for the selection and spread of bacterial resistance genes $[4,16,120]$, it is necessary to include green plant feedstuffs, such as alfalfa and grass, or microalgae. Even though, in this study, the use of the algae-containing feed additive Intivate was not sufficient, supplementation with microalgae is a suitable natural means of obtaining significant concentrations of php and pyp in swine manure. Microalgae, such as Chlorella vulgaris, which can be autochthonous to swine manure habitats $[121,122]$ presents a good source of chlorophyll $a$, php, and pyp $[38,40,123]$ as well as a valuable substitute for conventional protein sources [123, 124]. Their direct addition to swine waste lagoons, ponds, or other treatment bioreactors can be combined with the photodegradative bioremediation of residual antimicrobial substances $[125,126]$.

\section{Conclusions}

To conclude, this is the first study showing that pyropheophorbide derived from chlorophyll affects growth and the level of sensitivity to erythromycin of $S$. aureus, E. coli, and anaerobic manure bacteria. Addition of chlorophyllcontaining plant material to animal diets has the potential to reduce antibiotic resistance in the animal gut and eventual stored manure.

\section{Conflict of Interests}

The authors declare that there is no conflict of interests regarding the publication of this paper.

\section{Acknowledgments}

The authors thank Virve I. Enne, Centre for Immunology and Infectious Disease at Barts and The London School of Medicine and Dentistry, London, UK, for providing E. coli strains and the staff from the swine farm near Peoria, IL, for enabling sampling of swine stored manure and providing 
swine feed and data on feed composition and application of antimicrobials.

\section{References}

[1] E. K. Silbergeld, J. Graham, and L. B. Price, "Industrial food animal production, antimicrobial resistance, and human health," Annual Review of Public Health, vol. 29, pp. 151-169, 2008.

[2] G. Hansen, "Playing chicken with antibiotics: antibiotic use in food animals," in Proceedings of the 140th APHA Annual Meeting \& Exposition, San Francisco, Calif, USA, 2012.

[3] T. F. Landers, B. Cohen, T. E. Wittum, and E. L. Larson, "A review of antibiotic use in food animals: perspective, policy, and potential," Public Health Reports, vol. 127, no. 1, pp. 4-22, 2012.

[4] P. M. da Costa, L. Loureiro, and A. J. F. Matos, "Transfer of multidrug-resistant bacteria between intermingled ecological niches: the interface between humans, animals and the environment," International Journal of Environmental Research and Public Health, vol. 10, pp. 278-294, 2013.

[5] M. D. Apley, E. J. Bush, R. B. Morrison, R. S. Singer, and H. Snelson, "Use estimates of in-feed antimicrobials in swine production in the United States," Foodborne Pathogens and Disease, vol. 9, no. 3, pp. 272-279, 2012.

[6] D. C. Love, M. F. Davis, A. Bassett, A. Gunther, and K. E. Nachman, "Dose imprecision and resistance: free-choice medicated feeds in industrial food animal production in the United States," Environmental Health Perspectives, vol. 119, no. 3, pp. 279-283, 2011.

[7] F. Baquero, "Low-level antibacterial resistance: a gateway to clinical resistance," Drug Resistance Updates, vol. 4, no. 2, pp. 93-105, 2001.

[8] D. I. Andersson and D. Hughes, "Persistence of antibiotic resistance in bacterial populations," FEMS Microbiology Reviews, vol. 35, no. 5, pp. 901-911, 2011.

[9] R. Cantón and M.-I. Morosini, "Emergence and spread of antibiotic resistance following exposure to antibiotics," FEMS Microbiology Reviews, vol. 35, no. 5, pp. 977-991, 2011.

[10] M. A. van der Horst, J. M. Schuurmans, M. C. Smid, B. B. Koenders, and B. H. ter Kuile, "De novo acquisition of resistance to three antibiotics by escherichia coli," Microbial Drug Resistance, vol. 17, no. 2, pp. 141-147, 2011.

[11] D. I. Andersson and D. Hughes, "Evolution of antibiotic resistance at non-lethal drug concentrations," Drug Resistance Updates, vol. 15, pp. 162-172, 2012.

[12] R. Schmieder and R. Edwards, "Insights into antibiotic resistance through metagenomic approaches," Future Microbiology, vol. 7, no. 1, pp. 73-89, 2012.

[13] N. Peak, C. W. Knapp, R. K. Yang et al., "Abundance of six tetracycline resistance genes in wastewater lagoons at cattle feedlots with different antibiotic use strategies," Environmental Microbiology, vol. 9, no. 1, pp. 143-151, 2007.

[14] C. S. Hölzel, K. Schwaiger, K. Harms et al., "Sewage sludge and liquid pig manure as possible sources of antibiotic resistant bacteria," Environmental Research, vol. 110, no. 4, pp. 318-326, 2010.

[15] H. K. Allen, T. Looft, D. O. Bayles et al., "Antibiotics in feed induce prophages in swine fecal microbiomes," mBio, vol. 2, no. 6, 2011.

[16] T. Looft, T. A. Johnson, H. K. Allen et al., "In-feed antibiotic effects on the swine intestinal microbiome," Proceedings of the
National Academy of Sciences of the United States of America, vol. 109, no. 5, pp. 1691-1696, 2012.

[17] C. H. Bolster, "Factors controlling subsurface transport of manure-borne pathogens," 2012, http://www.extension.org/ pages/65647/microbes:-from-farm-to-public-risk.

[18] H. Heuer, H. Schmitt, and K. Smalla, "Antibiotic resistance gene spread due to manure application on agricultural fields," Current Opinion in Microbiology, vol. 14, no. 3, pp. 236-243, 2011.

[19] B. M. Marshall and S. B. Levy, "Food animals and antimicrobials: impacts on human health," Clinical Microbiology Reviews, vol. 24, no. 4, pp. 718-733, 2011.

[20] M. C. Roberts, "Environmental macrolide-lincosamide-streptogramin and tetracycline resistant bacteria," Frontiers in Microbiology, vol. 2, pp. 1-8, 2011.

[21] K. J. Forsberg, A. Reyes, B. Wang et al., "The shared antibiotic resistome of soil bacteria and human pathogens," Science, vol. 337, pp. 1107-1111, 2012.

[22] B. González-Zorn and J. A. Escudero, "Ecology of antimicrobial resistance: humans, animals, food and environment," International Microbiology, vol. 15, pp. 101-109, 2012.

[23] M. Popowska, M. Rzeczycka, A. Miernik, A. Krawczyk-Balska, F. Walsh, and B. Duffy, "Influence of soil use on prevalence of tetracycline,streptomycin, and erythromycin resistance and associated resistance genes," Antimicrobial Agents and Chemotherapy, vol. 56, no. 3, pp. 1434-1443, 2012.

[24] T. O. Rahube and C. K. Yost, "Characterization of a mobile and multiple resistance plasmid isolated from swine manure and its detection in soil after manure application," Journal of Applied Microbiology, vol. 112, pp. 1123-1133, 2012.

[25] B. Marquez, "Bacterial efflux systems and efflux pumps inhibitors," Biochimie, vol. 87, no. 12, pp. 1137-1147, 2005.

[26] M. Stavri, L. J. V. Piddock, and S. Gibbons, "Bacterial efflux pump inhibitors from natural sources," Journal of Antimicrobial Chemotherapy, vol. 59, no. 6, pp. 1247-1260, 2007.

[27] K. Poole, "Efflux-mediated antimicrobial resistance," Journal of Antimicrobial Chemotherapy, vol. 56, no. 1, pp. 20-51, 2005.

[28] J. L. Martínez and F. Rojo, "Metabolic regulation of antibiotic resistance," FEMS Microbiology Reviews, vol. 35, no. 5, pp. 768789, 2011.

[29] L. Fernandez and R. E. W. Hancock, "Adaptive and mutational resistance: role of porins and efflux pumps in drug resistance," Clinical Microbiology Reviews, vol. 25, pp. 661-681, 2012.

[30] T. A. Krulwich, O. Lewinson, E. Padan, and E. Bibi, "Do physiological roles foster persistance of drug/multidrug-efflux transporters? A case study," Nature Reviews Microbiology, vol. 3, no. 7, pp. 566-572, 2005.

[31] L. J. V. Piddock, "Multidrug-resistance efflux pumps-not just for resistance," Nature Reviews Microbiology, vol. 4, no. 8, pp. 629-636, 2006.

[32] X.-Z. Li and H. Nikaido, "Efflux-mediated drug resistance in bacteria: an update," Drugs, vol. 69, no. 12, pp. 1555-1623, 2009.

[33] A. C. Abreu, A. J. McBain, and M. Simoes, "Plants as sources of new antimicrobials and resistance-modifying agents," Natural Product Reports, vol. 29, pp. 1007-1021, 2012.

[34] A. Ojeda-Sana, V. Repetto, and S. Moreno, "Carnosic acid is an efflux pumps modulator by dissipation of the membrane potential in Enterococcus faecalis and Staphylococcus aureus," World Journal of Microbiology and Biotechnology, vol. 29, pp. 137-144, 2013. 
[35] J. G. Holler, S. B. Christensen, H.-C. Slotved et al., "Novel inhibitory activity of the Staphylococcus aureus NorA efflux pump by a kaempferol rhamnoside isolated from Persea lingue Nees," Journal of Antimicrobial Chemotherapy, vol. 67, no. 5, pp. 1138-1144, 2012.

[36] L. Ma and D. Dolphin, "The metabolites of dietary chlorophylls," Phytochemistry, vol. 50, no. 2, pp. 195-202, 1999.

[37] M. Holden, "Chlorophyll degradation products in leaf protein preparations," Journal of the Science of Food and Agriculture, vol. 25, no. 11, pp. 1427-1432, 1974.

[38] Y. Takeda, S. Uchiyama, and Y. Saito, "High performance liquid chromatography of pheophorbide a and pyropheophorbide a in salted vegetables and chlorella," Journal of the Food Hygienic Society of Japan, vol. 26, pp. 56-60, 1985.

[39] Y. Shioi, Y. Tatsumi, and K. Shimokawa, "Enzymatic degradation of chlorophyll in chenopodium album," Plant and Cell Physiology, vol. 32, no. 1, pp. 87-93, 1991.

[40] H. Oshima, E. Ueno, I. Saito, and H. Matsumoto, "Development of a solid-phase extraction method for determination of pheophorbide a and pyropheophorbide a in health foods by liquid chromatography," Journal of AOAC International, vol. 87, no. 4, pp. 937-942, 2004.

[41] S. Aiamla-or, S. Kaewsuksaeng, M. Shigyo, and N. Yamauchi, "Impact of UV-B irradiation on chlorophyll degradation and chlorophyll-degrading enzyme activities in stored broccoli (Brassica oleracea L. Italica Group) florets," Food Chemistry, vol. 120, no. 3, pp. 645-651, 2010.

[42] M. G. Ferruzzi, M. L. Failla, and S. J. Schwartz, "Assessment of degradation and intestinal cell uptake of carotenoids and chlorophyll derivatives from spinach puree using an in vitro digestion and Caco-2 human cell model," Journal of Agricultural and Food Chemistry, vol. 49, no. 4, pp. 2082-2089, 2001.

[43] K. D. Ashby, J. Wen, P. Chowdhury, T. A. Casey, M. A. Rasmussen, and J. W. Petrich, "Fluorescence of dietary porphyrins as a basis for real-time detection of fecal contamination on meat," Journal of Agricultural and Food Chemistry, vol. 51, no. 11, pp. 3502-3507, 2003.

[44] W. M. Campbell, G. S. Dombroski, I. Sharma, A. C. Partridge, and M. G. Collett, "Photodynamic chlorophyll a metabolites, including phytoporphyrin (phylloerythrin), in the blood of photosensitive livestock: overview and measurement," New Zealand Veterinary Journal, vol. 58, no. 3, pp. 146-154, 2010.

[45] M. Aprahamian, S. Evrardl, P. Keller et al., "Distribution of pheophorbide A in normal tissues and in an experimental pancreatic cancer in rats," Anti-Cancer Drug Design, vol. 8, no. 2, pp. 101-114, 1993.

[46] J. W. Jonker, M. Buitelaar, E. Wagenaar et al., "The breast cancer resistance protein protects against a major chlorophyllderived dietary phototoxin and protoporphyria," Proceedings of the National Academy of Sciences of the United States of America, vol. 99, no. 24, pp. 15649-15654, 2002.

[47] R. W. Robey, K. Steadman, O. Polgar, and S. E. Bates, "ABCG2mediated transport of photosensitizers: potential impact on photodynamic therapy," Cancer Biology and Therapy, vol. 4, no. 2, pp. 187-194, 2005.

[48] M. Li, H. Yuan, N. Li et al., "Identification of interspecies difference in efflux transporters of hepatocytes from dog, rat, monkey and human," European Journal of Pharmaceutical Sciences, vol. 35, no. 1-2, pp. 114-126, 2008.

[49] M. R. F. Lee, V. J. Theobald, H. J. Ougham et al., "Natural faecal fluorophores and the potential of chlorophyll based markers to optimise fluorescence as a real-time solution for the detection of faecal contamination on carcasses," Meat Science, vol. 86, no. 4, pp. 966-975, 2010.

[50] C. A. Barnes, S. L. Rasmussen, J. W. Petrich, and M. A. Rasmussen, "Determination of the concentration of potential efflux pump inhibitors, pheophorbide $a$ and pyropheophorbide $a$, in the feces of animals by fluorescence spectroscopy," Journal of Agricultural and Food Chemistry, vol. 60, pp. 10456-10460, 2012.

[51] F. R. Stermitz, J. Tawara-Matsuda, P. Lorenz, P. Mueller, L. Zenewicz, and K. Lewis, "5'-methoxyhydnocarpin-D and Pheophorbide A: Berberis species components that potentiate berberine growth inhibition of resistant Staphylococcus aureus," Journal of Natural Products, vol. 63, no. 8, pp. 1146-1149, 2000.

[52] R. Musumeci, A. Speciale, R. Costanzo et al., "Berberis aetnensis C. Presl. extracts: antimicrobial properties and interaction with ciprofloxacin," International Journal of Antimicrobial Agents, vol. 22, no. 1, pp. 48-53, 2003.

[53] M. C. Roberts, "Update on macrolide-lincosamide-streptogramin, ketolide, and oxazolidinone resistance genes," FEMS Microbiology Letters, vol. 282, no. 2, pp. 147-159, 2008.

[54] Compassion in World Farming, Antibiotics in animal farming, Public health and animal welfare, 2011, http://www.ciwf.org.uk/ includes/documents/cm_docs/2011/a/antibiotics_in_animal_ farming.pdf.

[55] S. Döhne, R. Merle, A. V. Altrock et al., "Antibiotic susceptibility of Salmonella, Campylobacter coli, and Campylobacter jejuni isolated from northern German fattening pigs," Journal of Food Protection, vol. 75, no. 10, pp. 1839-1845, 2012.

[56] H. Hao, Z. Yuan, Z. Shen et al., "Mutational and transcriptomic changes involved in the development of macrolide resistance in Campylobacter jejuni," Antimicrobial Agents and Chemotherapy, vol. 57, pp. 1369-1378, 2013.

[57] J. Olmstead, Institute for Agriculture and Trade Policy, Bugs in the system, How the FDA fails to regulate antibiotics in ethanol production, 2012, http://www.iatp.org/files/ 2012_05_02_AntibioticsInEthanol_JO_0.pdf.

[58] C. G. Shurson, D. M. Paulus, A. DiCostanzo et al., Are antibiotics a concern in distiller's co-products?, University of Minnesota, 2012, http://www.ddgs.umn.edu/prod/groups/cfans/ @pub/@cfans/@ddgs/documents/asset/cfans_asset_414344.pdf.

[59] FDA, U.S. Food and Drug Administration, Animal Drugs @ FDA, 2013, http://www.accessdata.fda.gov/scripts/animaldrugsatfda/.

[60] G. Tegos, F. R. Stermitz, O. Lomovskaya, and K. Lewis, "Multidrug pump inhibitors uncover remarkable activity of plant antimicrobials," Antimicrobial Agents and Chemotherapy, vol. 46, no. 10, pp. 3133-3141, 2002.

[61] Å. Aakra, H. Vebø, L. Snipen et al., “Transcriptional response of Enterococcus faecalis V583 to erythromycin," Antimicrobial Agents and Chemotherapy, vol. 49, no. 6, pp. 2246-2259, 2005.

[62] C. R. Jackson, P. J. Fedorka-Cray, J. B. Barrett, and S. R. Ladely, "Effects of tylosin use on erythromycin resistance in enterococci isolated from swine," Applied and Environmental Microbiology, vol. 70, no. 7, pp. 4205-4210, 2004.

[63] M. E. Jacob, J. T. Fox, S. K. Narayanan, J. S. Drouillard, D. G. Renter, and T. G. Nagaraja, "Effects of feeding wet corn distillers grains with solubles with or without monensin and tylosin on the prevalence and antimicrobial susceptibilities of fecal foodborne pathogenic and commensal bacteria in feedlot cattle," Journal of Animal Science, vol. 86, no. 5, pp. 1182-1190, 2008. 
[64] D. B. Holman and M. R. Chénier, "Impact of subtherapeutic administration of tylosin and chlortetracycline on antimicrobial resistance in farrow-to-finish swine," FEMS Microbiology Ecology, vol. 85, no. 1, pp. 1-13, 2013.

[65] J. M. Andrews, "Determination of minimum inhibitory concentrations," Journal of Antimicrobial Chemotherapy, vol. 48, no. 1, pp. 5-16, 2001.

[66] TOKU-E, Erythromycin (E-mycin, Ery-tab, Benzamycin), 2012, http://antibiotics.toku-e.com/antimicrobial_599.html.

[67] J. Liu, P. Keelan, P. M. Bennett, and V. I. Enne, "Characterization of a novel macrolide efflux gene, $\operatorname{mef}(\mathrm{B})$, found linked to sul 3 in porcine Escherichia coli," Journal of Antimicrobial Chemotherapy, vol. 63, no. 3, pp. 423-426, 2009.

[68] R. Lindqvist, "Estimation of Staphylococcus aureus growth parameters from turbidity data: characterization of strain variation and comparison of methods," Applied and Environmental Microbiology, vol. 72, no. 7, pp. 4862-4870, 2006.

[69] M. T. Madigan, J. M. Martinko, P. V. Dunlap, and D. P. Clark, "Growth of bacterial populations," in Brock Biology of Microorganisms, pp. 147-152, Pearson Education, San Francisco, Calif, USA, 2008.

[70] E. Bast, "Mikroskopische zellzählung in einer zählkammer," in Mikrobiologische Methoden: Eine Einführung in Grundlegende Arbeitstechniken, pp. 280-285, Spektrum-Akademischer Verlag, 2001, (German).

[71] K. P. Norris and E. O. Powell, "Improvements in determining total counts of bacteria," Journal of the Royal Microscopical Society, vol. 80, pp. 107-119, 1961.

[72] M. P. Bryant, "Commentary on the Hungate technique for culture of anaerobic bacteria," American Journal of Clinical Nutrition, vol. 25, no. 12, pp. 1324-1328, 1972.

[73] M. A. Cotta, T. R. Whitehead, and R. L. Zeltwanger, "Isolation, characterization and comparison of bacteria from swine faeces and manure storage pits," Environmental Microbiology, vol. 5, no. 9, pp. 737-745, 2003.

[74] S. Boisen and J. A. Fernández, "Prediction of the total tract digestibility of energy in feedstuffs and pig diets by in vitro analyses," Animal Feed Science and Technology, vol. 68, no. 3-4, pp. 277-286, 1997.

[75] J. Bindelle, A. Buldgen, C. Boudry, and P. Leterme, "Effect of inoculum and pepsin-pancreatin hydrolysis on fibre fermentation measured by the gas production technique in pigs," Animal Feed Science and Technology, vol. 132, no. 1-2, pp. 111-122, 2007.

[76] J. L. Wickliff and S. Aronoff, "Degradation of chlorophyll a to pheophytin $a$, pheophorbide $a$, and pyrroporphine XV for tracer studies," Analytical Biochemistry, vol. 6, no. 1, pp. 39-46, 1963.

[77] Miller Publishing Co., S. MicroSource, Direct-fed Microbial, Enzyme \& Forage Additive Compendium-Ninth Edition, 2013, http://www.microbialcompendium.com.

[78] EUCAST, European Committee on Antimicrobial Susceptibility Testing, Erythromycin/Staphylococcus aureus, EUCAST MIC Distribution, Version 5.13, 2013, http://mic.eucast.org/ Eucast2/regShow.jsp?Id=2642.

[79] EUCAST, European Committee on Antimicrobial Susceptibility Testing, Erythromycin/Enterococcus faecalis, EUCAST MIC Distribution, Version 5.13, 2013, http://mic.eucast.org/ Eucast2/regShow.jsp?Id=7183.

[80] J. L. Martinez, A. Fajardo, L. Garmendia et al., "A global view of antibiotic resistance," FEMS Microbiology Reviews, vol. 33, pp. 44-65, 2009.
[81] B. M. Jonas, B. E. Murray, and G. M. Weinstock, "Characterization of emeA, a norA homolog and multidrug resistance efflux pump, in Enterococcus faecalis," Antimicrobial Agents and Chemotherapy, vol. 45, no. 12, pp. 3574-3579, 2001.

[82] S. Gibbons, M. Oluwatuyi, and G. W. Kaatz, "A novel inhibitor of multidrug efflux pumps in Staphylococcus aureus," Journal of Antimicrobial Chemotherapy, vol. 51, no. 1, pp. 13-17, 2003.

[83] G. Belofsky, D. Percivill, K. Lewis, G. P. Tegos, and J. Ekart, "Phenolic metabolites of Dalea versicolor that enhance antibiotic activity against model pathogenic bacteria," Journal of Natural Products, vol. 67, no. 3, pp. 481-484, 2004.

[84] L. Unger and A. Kisch, "Observations on bacteriostatic and bactericidal action of erythromycin," Proceedings of the Society for Experimental Biology and Medicine, vol. 98, pp. 176-178, 1958.

[85] F. Fraschini, P. C. Braga, and V. Copponi, "Bactericidal activity of erythromycin in the respiratory system," Current Medical Research and Opinion, vol. 7, no. 7, pp. 429-439, 1981.

[86] G. A. Pankey and L. D. Sabath, "Clinical relevance of bacteriostatic versus bactericidal mechanisms of action in the treatment of gram-positive bacterial infections," Clinical Infectious Diseases, vol. 38, no. 6, pp. 864-870, 2004.

[87] H. Nikaido, "Multidrug resistance in bacteria," Annual Review of Biochemistry, vol. 78, pp. 119-146, 2009.

[88] J. L. Martínez, F. Baquero, and D. I. Andersson, "Beyond serial passages: new methods for predicting the emergence of resistance to novel antibiotics," Current Opinion in Pharmacology, vol. 11, no. 5, pp. 439-445, 2011.

[89] E. Piątkowska, J. Piątkowski, and A. Przondo-Mordarska, "The strongest resistance of Staphylococcus aureus to erythromycin is caused by decreasing uptake of the antibiotic into the cells," Cellular and Molecular Biology Letters, vol. 17, pp. 633-645, 2012.

[90] E. J. C. Goldstein and V. L. Sutter, "Effect of carbon dioxide on erythromycin," Antimicrobial Agents and Chemotherapy, vol. 23, no. 2, pp. 325-327, 1983.

[91] L. M. Ednie, M. R. Jacobs, and P. C. Appelbaum, "Anti-anaerobic activity of erythromycin, azithromycin and clarithromycin: effect of $\mathrm{pH}$ adjustment of media to compensate for $\mathrm{pH}$ shift caused by incubation in $\mathrm{CO}_{2}$," Journal of Antimicrobial Chemotherapy, vol. 41, no. 3, pp. 387-389, 1998.

[92] T. T. Luong, P. M. Dunman, E. Murphy, S. J. Projan, and C. Y. Lee, "Transcription profiling of the $m g r A$ regulon in Staphylococcus aureus," Journal of Bacteriology, vol. 188, no. 5, pp. 1899-1910, 2006.

[93] K. Poole, "Bacterial stress responses as determinants of antimicrobial resistance," Journal of Antimicrobial Chemotherapy, vol. 67, pp. 2069-2089, 2012.

[94] Q. C. Truong-Bolduc, L. C. Hsing, R. Villet et al., "Reduced aeration affects the expression of the NorB efflux pump of Staphylococcus aureus by posttranslational modification of MgrA," Journal of Bacteriology, vol. 194, no. 7, pp. 1823-1834, 2012.

[95] R. Leclercq, "Mechanisms of resistance to macrolides and lincosamides: nature of the resistance elements and their clinical implications," Clinical Infectious Diseases, vol. 34, no. 4, pp. 482492, 2002.

[96] V. A. Luna, M. Heiken, K. Judge et al., "Distribution of mef(A) in gram-positive bacteria from healthy Portuguese children," Antimicrobial Agents and Chemotherapy, vol. 46, no. 8, pp. 25132517, 2002. 
[97] J. L. Floyd, K. P. Smith, S. H. Kumar, J. T. Floyd, and M. F. Varela, "LmrS is a multidrug efflux pump of the major facilitator superfamily from Staphylococcus aureus," Antimicrobial Agents and Chemotherapy, vol. 54, no. 12, pp. 5406-5412, 2010.

[98] G. W. Kaatz, V. V. Moudgal, S. M. Seo, J. B. Hansen, and J. E. Kristiansen, "Phenylpiperidine selective serotonin reuptake inhibitors interfere with multidrug efflux pump activity in Staphylococcus aureus," International Journal of Antimicrobial Agents, vol. 22, no. 3, pp. 254-261, 2003.

[99] K. A. Hassan, R. A. Skurray, and M. H. Brown, "Active export proteins mediating drug resistance in staphylococci," Journal of Molecular Microbiology and Biotechnology, vol. 12, no. 3-4, pp. 180-196, 2007.

[100] J. Huang, P. W. O’Toole, W. Shen et al., "Novel chromosomally encoded multidrug efflux transporter MdeA in Staphylococcus aureus," Antimicrobial Agents and Chemotherapy, vol. 48, no. 3, pp. 909-917, 2004.

[101] J. I. Ross, E. A. Eady, J. H. Cove, and S. Baumberg, "Minimal functional system required for expression of erythromycin resistance by msrA in Staphylococcus aureus RN4220," Gene, vol. 183, no. 1-2, pp. 143-148, 1996.

[102] K. Kadlec, A. T. Feßler, T. Hauschild, and S. Schwarz, "Novel and uncommon antimicrobial resistance genes in livestockassociated methicillin-resistant Staphylococcus aureus," Clinical Microbiology and Infection, vol. 18, pp. 745-755, 2012.

[103] C. R. S. Teodoro, C. S. Mattos, F. S. Cavalcante, E. M. Pereira, and K. R. N. dos Santos, "Characterization of MLS ${ }_{b}$ resistance among Staphylococcus aureus and Staphylococcus epidermidis isolates carrying different SCCmec types," Microbiology and Immunology, vol. 56, pp. 647-650, 2012.

[104] M. A. Argudín, B.-A. Tenhagen, A. Fetsch et al., "Virulence and resistance determinants of German Staphylococcus aureus ST398 isolates from nonhuman sources," Applied and Environmental Microbiology, vol. 77, no. 9, pp. 3052-3060, 2011.

[105] Z. Zhou, L. Raskin, and J. L. Zilles, "Macrolide resistance in microorganisms at antimicrobial-free swine farms," Applied and Environmental Microbiology, vol. 75, no. 18, pp. 5814-5820, 2009.

[106] M. Kalmokoff, L. M. Waddington, M. Thomas et al., "Continuous feeding of antimicrobial growth promoters to commercial swine during the growing/finishing phase does not modify faecal community erythromycin resistance or community structure," Journal of Applied Microbiology, vol. 110, no. 6, pp. 1414-1425, 2011.

[107] Santa Cruz Biotechnology, Tylosin tartrate (CAS, 1405-54-5), Material Safety Data Sheet, 2013, http://datasheets.scbt.com/sc204933.pdf.

[108] M. C. Roberts, "Resistance to macrolide, lincosamide, streptogramin, ketolide, and oxazolidinone antibiotics," Molecular Biotechnology, vol. 28, no. 1, pp. 47-62, 2004.

[109] C. Baker-Austin, M. S. Wright, R. Stepanauskas, and J. V. McArthur, "Co-selection of antibiotic and metal resistance," Trends in Microbiology, vol. 14, no. 4, pp. 176-182, 2006.

[110] J. L. Martinez, M. B. Sánchez, L. Martínez-Solano et al., "Functional role of bacterial multidrug efflux pumps in microbial natural ecosystems," FEMS Microbiology Reviews, vol. 33, no. 2, pp. 430-449, 2009.

[111] J. Kluytmans and J. L. Murk, "Lincomycin and clindamycin," in Kucers' the Use of Antibiotics: A Clinical Review of Antibacterial, Antifungal and Antiviral Drugs, L. M. Grayson, Ed., pp. 9871007, CRC Press, Boca Raton, Fla, USA, 2010.
[112] C. S. Hölzel, C. Müller, K. S. Harms et al., "Heavy metals in liquid pig manure in light of bacterial antimicrobial resistance," Environmental Research, vol. 113, pp. 21-27, 2012.

[113] R. Leclercq, R. Cantón, D. F. J. Brown et al., "EUCAST expert rules in antimicrobial susceptibility testing," Clinical Microbiology and Infection, vol. 19, pp. 141-160, 2013.

[114] A. P. Gerola, A. Santana, P. B. França et al., "Effects of metal and the phytyl chain on chlorophyll derivatives: physicochemical evaluation for photodynamic inactivation of microorganisms," Photochemistry and Photobiology, vol. 87, no. 4, pp. 884-894, 2011.

[115] A. Bolotin, P. Wincker, S. Mauger et al., "The complete genome sequence of the lactic acid bacterium lactococcus lactis ssp. lactis IL1403," Genome Research, vol. 11, no. 5, pp. 731-753, 2001.

[116] F. R. Stermitz, T. D. Beeson, P. J. Mueller, J.-F. Hsiang, and K. Lewis, "Staphylococcus aureus MDR efflux pump inhibitors from a Berberis and a Mahonia (sensu strictu) species," Biochemical Systematics and Ecology, vol. 29, no. 8, pp. 793-798, 2001.

[117] L. J. V. Piddock, "Clinically relevant chromosomally encoded multidrug resistance efflux pumps in bacteria," Clinical Microbiology Reviews, vol. 19, no. 2, pp. 382-402, 2006.

[118] T. R. Whitehead and M. A. Cotta, "Characterisation and comparison of microbial populations in swine faeces and manure storage pits by $16 \mathrm{~S}$ rDNA gene sequence analyses," Anaerobe, vol. 7, no. 4, pp. 181-187, 2001.

[119] R. Snell-Castro, J.-J. Godon, J.-P. Delgenès, and P. Dabert, "Characterisation of the microbial diversity in a pig manure storage pit using small subunit rDNA sequence analysis," FEMS Microbiology Ecology, vol. 52, no. 2, pp. 229-242, 2005.

[120] A. Tello, B. Austin, and T. C. Telfer, "Selective pressure of antibiotic pollution on bacteria of importance to public health," Environmental Health Perspectives, vol. 120, pp. 1100-1106, 2012.

[121] M. Wilson and J. A. Houghton, "Growth of algae on pig manure," Irish Journal of Agricultural Research, vol. 13, pp. 4960, 1974.

[122] M. V. Jiménez-Pérez, P. Sánchez-Castillo, O. Romera, D. Fernández-Moreno, and C. Pérez-Martínez, "Growth and nutrient removal in free and immobilized planktonic green algae isolated from pig manure," Enzyme and Microbial Technology, vol. 34, pp. 392-398, 2004.

[123] M. K. Garrett, J. J. Strain, and M. D. B. Allen, "Composition of the product of algal culture in the liquid phase of animal slurry," Journal of the Science of Food and Agriculture, vol. 27, pp. 603611, 1976.

[124] E. W. Becker, "Micro-algae as a source of protein," Biotechnology Advances, vol. 25, no. 2, pp. 207-210, 2007.

[125] I. de Godos, R. Muñoz, and B. Guieyssea, “Tetracycline removal during wastewater treatment in high-rate algal ponds," Journal of Hazardous Materials, vol. 229-230, pp. 446-449, 2012.

[126] E. M. Ferrero, I. de Godos, E. M. Rodríguez, P. A. GarcíaEncina, R. Muñoz, and E. Bécares, "Molecular characterization of bacterial communities in algal-bacterial photobioreactors treating piggery wastewaters," Ecological Engineering, vol. 40, pp. 121-130, 2012. 

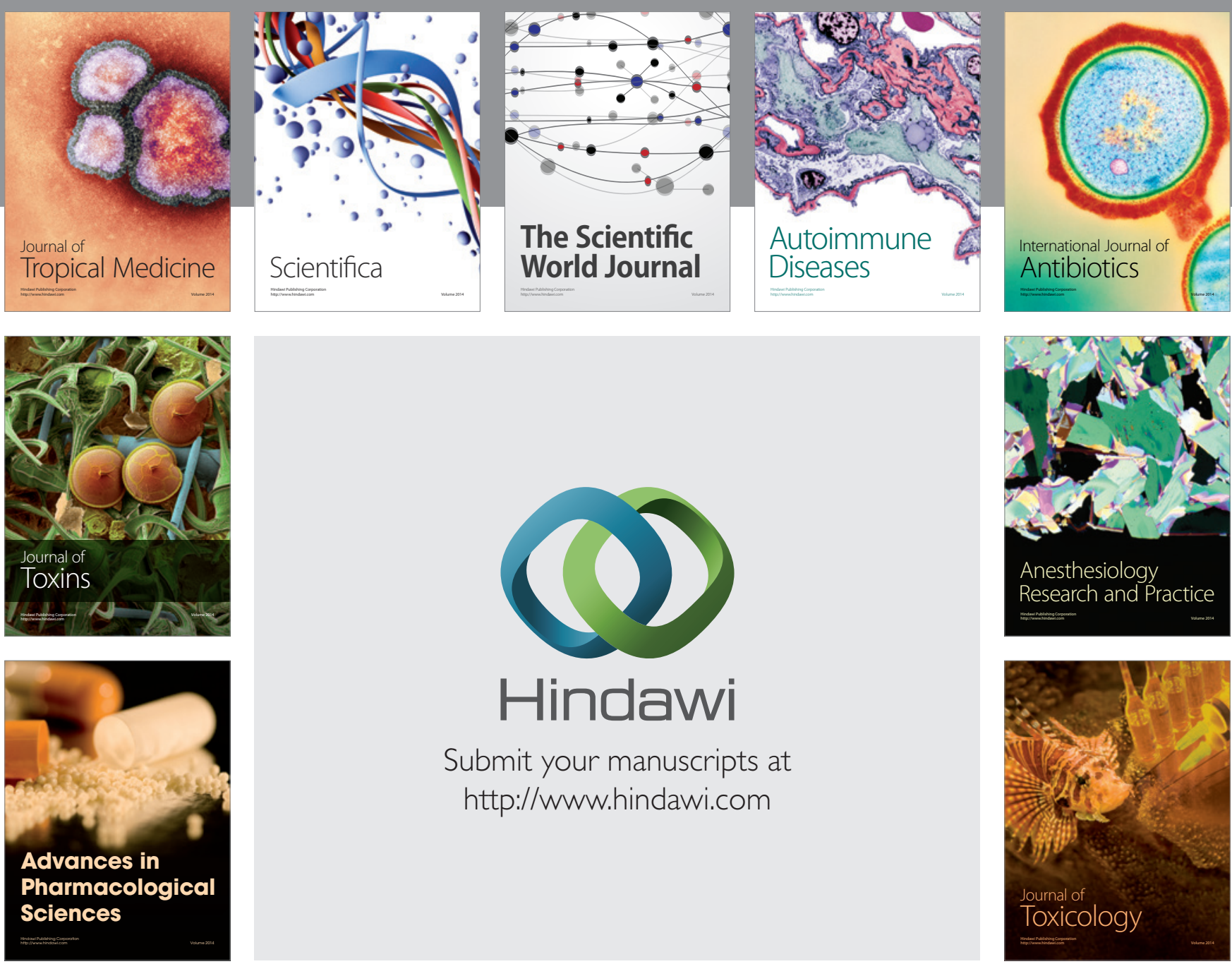

\section{Hindawi}

Submit your manuscripts at

http://www.hindawi.com
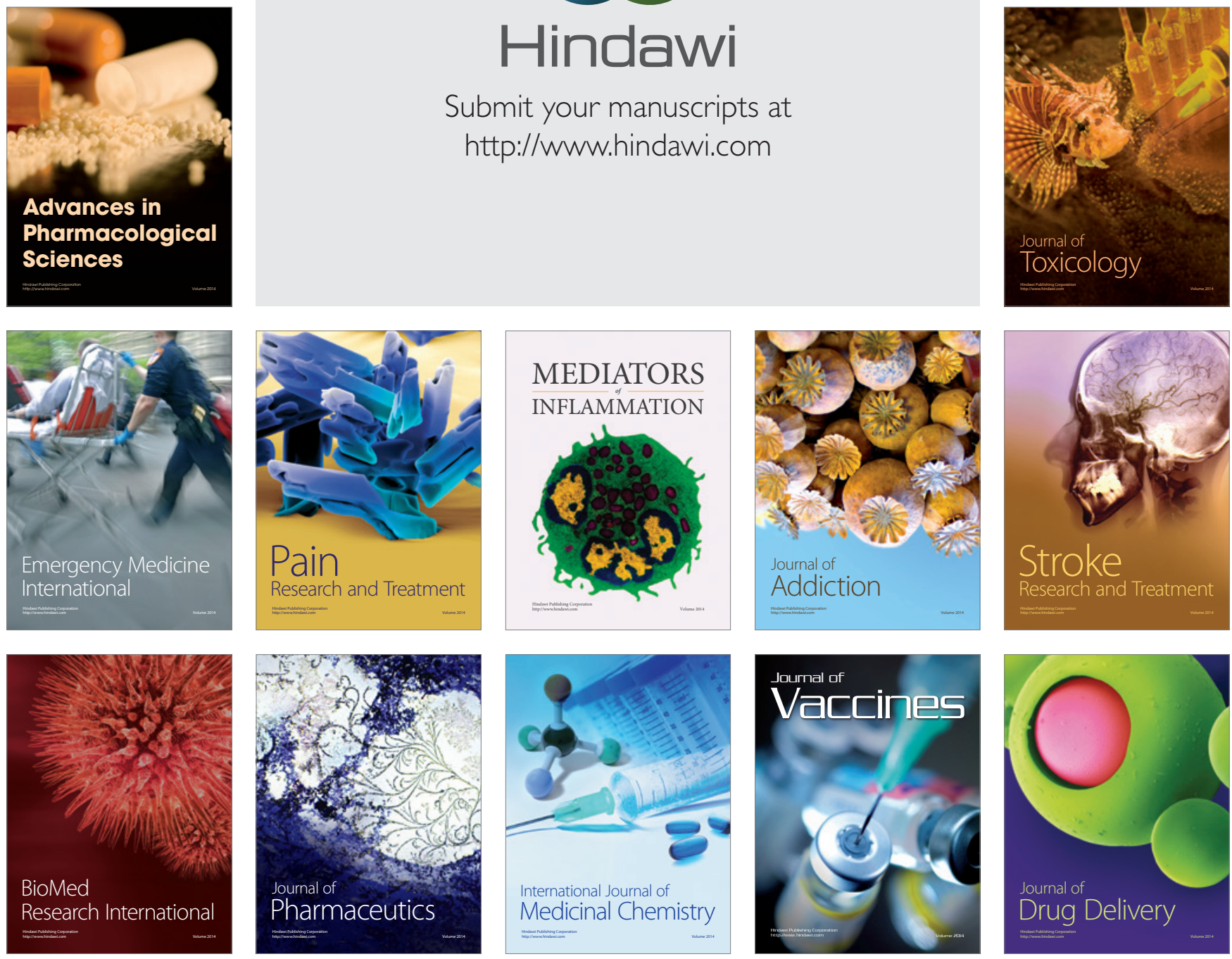